\title{
DES Overview: A Historical and Current Review of Pivotal Clinical Trial Programs
}

\author{
Susan Bezenek, Poornima Sood, Wes Pierson, \\ Chuck Simonton and Krishna Sudhir \\ Abbott Vascular, Santa Clara, CA
} USA

\section{Introduction}

The focus of this chapter is drug-eluting stents (DES) for the treatment of coronary artery disease (CAD). The clinical trial programs for the main DES approved by the Food and Drug Administration (FDA) for the treatment of CAD are presented. CAD is the leading cause of death in both men and women around the world. In the United States alone, there is a coronary event that occurs every 25 seconds and someone will die from a coronary event every minute (Roger et al., 2011). The current treatment options for ischemic CAD include medications, percutaneous interventions, and surgery to perform coronary artery bypass grafting (CABG). According to the American Heart Association (AHA) 2011 Statistics Update, the total number of percutaneous coronary interventions (PCI) procedures performed in 2007 was 1,178,000 compared to 408,000 CABG operations. With risk factors like obesity and diabetes prevalence increasing globally, the number of CAD interventions will likely continue to rise in the future and require more specialized treatment options for more complex lesions and patient populations.

In past decades, percutaneous angioplasty (PTCA) or plain old balloon angioplasty (POBA) was used to treat obstructive coronary lesions but had frequent incidence of abrupt closure and restenosis. The use of bare metal stents (BMS) helped to address the limitations of PTCA, as evident by reduced angiographic restenosis and target vessel revascularizations (TVR) in earlier clinical trials. The results of these trials led to the first FDA approved balloon-expandable BMS, the Palmaz-Schatz stent (Cordis Corp; a Johnson and Johnson Company) and the Gianturco-Roubin coil stent (Cook Inc, Bloomington, IN) (Fischman et al., 1994; Serruys et al., 1994). Compared to PTCA, the development of BMS reduced the need for urgent $C A B G$ associated with abrupt closures and restenosis, but the need for repeat procedures persisted (Doostzadeh et al., 2010). Although BMS provided the structural support to prevent abrupt closures, arterial wall recoil, and negative arterial wall remodeling, the problem of neointimal hyperplasia was not remedied by BMS. Some of the earlier trials evaluating BMS demonstrated that restenosis occurred in about $20 \%$ of cases by 6 months (Doostzadeh et al., 2009). The development of DES emerged and intended to deliver localized pharmaceutical agents targeted to reduce restenosis.

In order for DES to optimize therapeutic benefits with minimal risks, several factors must be considered. The stent cell design, strut thickness, polymer technology, mechanism of drug, 
and pharmacokinetics must all be considered to minimize vessel injury and prevent delayed healing while allowing appropriate endothelialization and avoiding loss of coating integrity, especially during stent delivery and expansion. In order to evaluate the safety and efficacy of DES, the early trials were designed with a BMS comparator arm and used similar endpoints as the previous BMS trials. DES were originally compared to BMS in the RAVEL, TAXUS I, ENDEAVOR I, and SPIRIT FIRST first-in-man clinical trials. These early clinical trials favored the DES arms with reduction in restenosis, major adverse cardiac events (MACE), and revascularizations compared to BMS (Grube et al., 2003; Morice et al., 2002; Moses et al., 2003; Serruys et al., 2002a). DES appeared to address the needs for safe and efficacious PCI for ischemic coronary arterial disease. The underlying metal stent of a DES system provided the structural support to reduce abrupt closure and recoil, while covering the outside of the stent with a platform to deliver pharmaceutical agents that reduced neointimal hyperplasia. As a result, DES replaced BMS as the predominant PCI therapy for suitable patients over the past decade. To date, there are four main commercially available DES manufacturers in the U.S. that will be highlighted in this chapter; Cordis-Johnson and Johnson, Boston Scientific, Medtronic, and Abbott Vascular. Although improved clinical outcomes with these DES have been evident, the risk of stent thrombosis (ST) was previously believed to be one of the potential draw backs of DES compared to BMS. The FDA Circulatory Advisory Panel released a statement following an extensive panel review of trial results and noted that there was no subsequent increase in deaths or MIs from ST in patients treated with DES per the on-label, approved indication (FDA, 2006). The use of dual antiplatelet therapy (DAPT) has been recommended up to 12 months following the procedure in patients that are not at high risk for bleeding per the ACCF/AHA/SCAI 2007 guidelines (King, 2007). The ideal duration of DAPT continues to be explored as DES is now utilized in more high risk patients and in real-world settings. The current improvements for DES focus on drug delivery platforms and bioresorbable stents that may remove potential contributing factors of the stent that cause stent thrombosis. Therefore, this chapter will conclude with an overview of new stent technology currently being evaluated in clinical trials.

\section{CYPHER ${ }^{\circledR}$ and NEVO ${ }^{\mathrm{TM}}$}

The first DES to be approved in the U.S by the FDA in 2003 was CYPHER, manufactured by Cordis Corp; a Johnson and Johnson Company. The CYPHER stent is the Bx Velocity bare metal stent comprised of $316 \mathrm{~L}$ stainless steel and has three non-eroding polymer coatings with the active drug, sirolimus loaded throughout the coating, but outside of the stent. The basecoat of the stent contains a combination of two non-erodible polymers; n-butyl methylacrylate (PBMA) and polyethylene co-vinyl acetate (PEVA). The two polymers are mixed in a combination with the sirolimus and applied to a parylene $\mathrm{C}$ treated stent, which is covered lastly by a drug-free polymer coating of PBMA (accessed online at http://www.cordislabeling.com). The polymer coating thickness is $13.7 \mu \mathrm{m}$ and as an early stent design, the strut thickness is subsequently one of thickest $(140 \mu \mathrm{m})$. The CYPHER stent sizes available range from $8 \mathrm{~mm}-33 \mathrm{~mm}$ long and diameter sizes of $2.25 \mathrm{~mm}-3.50 \mathrm{~mm}$ with a maximum sirolimus dose of $314 \mu \mathrm{g}$. Sirolimus (rapamycin) has lipophilic properties that favor the diffusion across cell membranes of the smooth muscle cells. It is not well understood, but thought that once in the cell, sirolimus binds to the FKBP12 cytoplasmic intracellular protein, which subsequently inhibits the mammalian target of rapamycin 
(mTOR) regulatory enzyme. The inhibition of mTOR interrupts the cell cycle at the G1 phase and will subsequently inhibit proliferation of smooth muscle cells (Sousa et al., 2001).

The CYPHER stent was approved for commercialization in the U.S. based on the results from the RAVEL and SIRIUS trials. The CYPHER stent received a clinical indication to improve coronary artery lumen diameter in patients with ischemic de novo coronary lesions measuring $\leq 30 \mathrm{~mm}$ long in native coronary arteries measuring $\geq 2.25 \mathrm{~mm}$ and $\leq 3.5 \mathrm{~mm}$ in diameter (accessed online at http://www.cordislabeling.com). The RAVEL study was a randomized, multicenter, double-blind trial that evaluated the CYPHER sirolimus-eluting stent system (SES) compared to the Bx Velocity BMS in single de novo coronary lesion treatable by a single $18 \mathrm{~mm}$ length stent. The trial enrolled 120 patients in the CYPHER arm and 118 patients in the control (BMS) arm. As reported by Morice et al. and Serruys et al. (2002) (Morice et al., 2002; Serruys et al., 2002b), the primary endpoint of in-stent late loss (LL) favored the CYPHER arm and the angiographic binary restenosis (ABR) rate was $0 \%$ in the CYPHER arm compared to $26.6 \%$ in the BMS arm at 6 months. The CYPHER arm also favored in clinical endpoint results, as no events of target lesion revascularization (TLR) or target vessel revascularization (TVR) occurred at one year, compared to the BMS arm rates of $23.7 \%$ and $26.0 \%$, respectively (Morice et al., 2002; Serruys et al., 2002b). With the promising results demonstrated in the RAVEL trial, the CYPHER stent was evaluated in longer lesions between 15 and $33 \mathrm{~mm}$ in length in the SIRIUS trial. There were 533 patients enrolled in the CYPHER arm and 525 patients in the Bx Velocity arm. The SIRIUS trial was a randomized 1:1 multicenter trial and was the pivotal trial that led to FDA approval in the U.S. Compared to the RAVEL trial, the SIRIUS trial enrolled patients with more complex characteristics, such as diabetes, overlapping stent usage, and longer lesions. The mean lesion length in the CYPHER sirolimus-eluting stent system (SES) arm in the RAVEL trial was $9.56 \mathrm{~mm}$ compared to $14.4 \mathrm{~mm}$ in the SIRIUS trial (Htay and Liu, 2005). The primary endpoint was target vessel failure (TVF; defined as target vessel revascularization, cardiac death or Q-wave and non-Q-wave MI not clearly attributed to a vessel other than the target vessel) and showed statistical significance in favor of the SES arm compared to the Bx Velocity BMS arm, respectively $(8.8 \%$ versus $21.0 \%, \mathrm{p}<0.001)$ and also demonstrated significant reductions in TLR rates for the SES arm compared to the BMS arm at 1 year, respectively $(4.1 \%$ versus $16.6 \%$, p < 0.001) (Holmes, 2003).

Trials conducted in Europe and Canada that evaluated CYPHER compared to the Bx Velocity, the E-SIRIUS and C-SIRIUS trials showed consistent results that favored the SES arms compared to the BMS arms. The TLR rates remained numerically lower in the SES arm $(4.0 \%)$ compared to the BMS arm $(20.9 \%)$ in the E-SIRIUS trial and also the C-SIRIUS trial (4.0\% versus $18.0 \%$, respectively) (Schampaert et al., 2004; Schofer et al., 2003). Following FDA approval in 2003, post-marketing surveillance was initiated in the CYPHER Stent PostMarket Registry in 2003 and the e-SELECT post-market Registry in 2006. The post-market trials were designed as open-label, single-arm, multicenter trials that enrolled real-world treated patients. The CYPHER Stent Post-market registry enrolled up to 15,000 patients and the e-SELECT trial enrolled up to 2070 patients to continue monitoring safety and surveillance required by the FDA. Since the initial approval, multiple registries out of the U.S (OUS) have been initiated as well, such as in Israel, China, and India. The SIRIUS 2.25 $\mathrm{mm}$ pivotal trial was conducted to evaluate the safety and efficacy of the SES $2.25 \mathrm{~mm}$ stent for the reduction of angiographic binary restenosis at 6 months in patients with reference vessel diameters between 2.0 and $2.5 \mathrm{~mm}$ and lesion lengths $\leq 20 \mathrm{~mm}$. The trial was a non- 
randomized, multicenter, prospective trial that compared propensity scores matched results from plain old balloon angioplasty (POBA), Palmaz Schatz, and Bx VELOCITY to the SES $2.25 \mathrm{~mm}$ treated patients. The outcomes were favorable for the SES $2.25 \mathrm{~mm}$ stent arm and were consistent with previous CYPHER trials. Table 1 below highlights the first-in-man (FIM), pivotal, and post-marketing trials conducted for the CYPHER DES.

\begin{tabular}{|c|c|c|c|c|c|c|}
\hline Trial & Design & $\begin{array}{c}\text { Sample } \\
\text { size }\end{array}$ & $\begin{array}{l}\text { Primary } \\
\text { endpoint }\end{array}$ & $\begin{array}{c}\text { SES } \\
\text { treatment } \\
\text { arm } \\
\end{array}$ & $\begin{array}{c}\text { BMS } \\
\text { treatment } \\
\text { arm } \\
\end{array}$ & $P$ value \\
\hline RAVEL & $\begin{array}{c}\text { Randomized, } \\
\text { multi-center }\end{array}$ & 238 & $\begin{array}{c}\text { In-stent late } \\
\text { loss at } 6 \\
\text { months }\end{array}$ & $\begin{array}{c}0.01 \pm 0.33 \\
\mathrm{~mm}\end{array}$ & $\begin{array}{c}0.80 \pm 0.53 \\
\mathrm{~mm}\end{array}$ & $\mathrm{P}<0.001$ \\
\hline SIRIUS & $\begin{array}{l}\text { Randomized } \\
\text { multicenter }\end{array}$ & 1,058 & $\begin{array}{c}\text { Target } \\
\text { vessel } \\
\text { failure } \\
(\mathrm{TVF})^{*} \text { at } 9 \\
\text { months }\end{array}$ & $8.6 \%$ & $21.0 \%$ & $\mathrm{P}<0.001$ \\
\hline $\begin{array}{l}\text { CYPHER Post- } \\
\text { Marketing } \\
\text { Surveillance } \\
\text { Registry (2003) }\end{array}$ & $\begin{array}{l}\text { Open label, } \\
\text { single arm, } \\
\text { multicenter }\end{array}$ & 2067 & $\begin{array}{c}\text { Major } \\
\text { adverse } \\
\text { cardiac } \\
\text { event } \\
\text { (MACE) } \\
\text { and TLR at } \\
1 \text { year }\end{array}$ & $\begin{array}{c}\text { MACE } \\
7.3 \% \\
\text { TLR } 4.6 \%\end{array}$ & $\begin{array}{c}\text { Not } \\
\text { applicable } \\
\text { (NA) }\end{array}$ & $\begin{array}{c}\text { Not } \\
\text { applicable } \\
\text { (NA) }\end{array}$ \\
\hline $\begin{array}{c}\text { e-SELECT } \\
\text { Registry (2006) }\end{array}$ & $\begin{array}{l}\text { Open label, } \\
\text { single arm, } \\
\text { multicenter }\end{array}$ & 15,000 & $\begin{array}{l}\text { Composite } \\
\text { of stent } \\
\text { thrombosis } \\
\text { (ST) per } \\
\text { ARC- } \\
\text { definite/ } \\
\text { probable at } \\
3 \text { years }\end{array}$ & $\begin{array}{c}1.0 \% \text { (1 yr) } \\
\text { (3 yr data } \\
\text { not } \\
\text { available } \\
\text { to date) }\end{array}$ & $\begin{array}{c}\text { Not } \\
\text { applicable } \\
\text { (NA) }\end{array}$ & $\begin{array}{c}\text { Not } \\
\text { applicable } \\
\text { (NA) }\end{array}$ \\
\hline
\end{tabular}

*TVF = target vessel revascularization, cardiac death, or Q-wave and non-Q-wave MI not clearly attributed to a vessel other than the target vessel. ${ }^{\triangle \mathrm{MACE}}=$ death, $\mathrm{Q}$-wave and non-Q-wave MI, and emergent coronary artery bypass graft (CABG), target lesion revascularization (TLR).

Table 1. Clinical trials evaluating the CYPHER SES

One of the challenges faced with these earlier pivotal trials (SIRIUS and RAVEL) was the small sample sizes that were underpowered to discern differences in stent thrombosis (ST) rates between the DES and the BMS arms (Morice et al., 2007; Weisz et al., 2006). As registries collected data on larger populations, a potential increased safety risk of stent thrombosis was questioned with DES use compared to BMS (Lagerqvist et al., 2007; Moreno et al., 2005). During the 2006 FDA Circulatory Advisory Panel, it was concluded that expanded use of DES beyond the approved indication in more complex patients may contribute to the incidence of ST in DES (FDA, 2006). The antiplatelet medication recommendations were also modified to extend clopidogrel usage for up to 12 months for 
those patients treated with DES that are not at high risk for bleeding in order to potentially reduce ST events (King et al., 2007). As more long term data has become available over the past decade, the concern for increased ST in DES has diminished while strategic new stent technology has been evolving into next generation stent designs.

The next generation of DES under development by Cordis is the NEVO ${ }^{\mathrm{TM}}$ sirolimus-eluting stent system (NEVO SES) that has a cobalt chromium alloy platform with reservoirs loaded with a bioabsorbable polymer, polyglycolic lactic acid (PGLA), combined with sirolimus. The strut thickness $(100 \mu \mathrm{m})$ is thinner than the original CYPHER SES platform and there is an open-cell design that may aid in conformability and flexibility. One of the potential benefits of the reservoir technique for localized drug delivery on a stent, is that the surface area of polymer exposure to the vessel is reduced, which may help to reduce sensitivity or inflammatory responses to polymer that result in events. Furthermore, the NEVO SES elutes sirolimus within 90 days from implant while the PGLA degrades, leaving only a bare metal scaffold in place which may help reduce ST attributed to permanent polymer coatings (Otake et al., 2011a).

The NEVO ResElution-1 trial was a randomized, multicenter, prospective trial that was designed to demonstrate the non-inferiority of NEVO SES compared to a second generation paclitaxel-eluting stent (PES), the TAXUS ${ }^{\circledR}$ Liberte' ${ }^{\circledR}$ PES (see 3.0 below) in terms of in-stent late loss at 6 months. The trial enrolled 394 patients and met the primary endpoint; NEVO SES was non-inferior to TAXUS Liberté for in-stent late loss, respectively $(0.13 \pm 0.31$ and $0.36 \pm 48, \mathrm{p}<0.001$ ) and demonstrated more uniform suppression of neointimal hyperplasia (Spaulding, 2011). Numerically lower rates of MACE, death, MI, and revascularization have also been demonstrated in favor of the NEVO SES arm compared to the TAXUS Liberte arm through 24 months, as well as no events of ST in the NEVO SES arm (Spaulding, 2011). The NEVO ResElution-1 IVUS sub-study was also conducted and enrolled 100 patients and had 3D intravascular ultrasound (IVUS) studies available on 64 patients at 6 months, which showed that a significant reduction in neointimal obstruction occurred in the NEVO SES arm $(5.5 \pm 11.0 \%)$ compared to the TAXUS Liberte arm $(11.5 \pm 9.7 \%), p=0.02$ (Otake et al., 2011a). There was no event of ST in the NEVO SES arm at 6 months compared to 1 event in the TAXUS Liberté arm, and clinical outcomes were overall comparable for death, MI, and TLR (Otake et al., 2011a). Long-term follow-up will continue in the NEVO-SES trial through 5 years. On June 15th, 2011 however, it was announced that CYPHER and NEVO clinical trial programs would be ending due to production cost and declining market share, thus ending future CYPHER-biodegradable new stent technologies for the treatment of CAD.

\section{TAXUS ${ }^{\circledR}$ and PLATINUM ${ }^{\text {TM }}$}

The TAXUS Express ${ }^{2 \mathrm{TM}}$ paclitaxel eluting stent system (PES) was initially approved by the FDA in 2004, becoming the second DES to be commercially available in the U.S. The TAXUS Express 2 PES utilizes paclitaxel as the active drug agent, which is a plant based alkaloid that disrupts the cellular microtubules by binding to tubulin and subsequently arrests the cell cycle at the M phase (Rowinsky and Donehower, 1995). The earliest TAXUS DES implanted in humans was the NIR ${ }^{\mathrm{TM}}$ stainless steel closed cell design. The uncoated NIR BMS was used as the scaffold in the TAXUS I, II, and III trials and it is coated with a paclitaxel dose of 1 $\mu \mathrm{g} / \mathrm{mm}^{2}$ (Halkin and Stone, 2004). The biphasic polymer-controlled drug release of this stent 
design elutes paclitaxel in two phases; an initial burst release phase within the first 48 hours followed by a slower release phase over the next 10 days (Halkin and Stone, 2004). The TAXUS Express ${ }^{1}$ and TAXUS Express ${ }^{2}$ were later utilized in the pivotal trials (TAXUS IV and TAXUS V) and also had a stainless steel platform with tandem cell architecture and strut thickness of $132 \mu \mathrm{m}$ and a non-degradable TRANSLUTE ${ }^{\mathrm{TM}}$ polymer-coating containing paclitaxel. The TRANSLUTE polymer coating thickness is approximately $16 \mu \mathrm{m}$ and consists of polylactide-co-caprolactone, which provides a uniform and controlled release of paclitaxel with a drug density of $1 \mu \mathrm{g} / \mathrm{mm}^{2}$ (Hellige and Windecker, 2009). There are three profiles that were developed and the paclitaxel to polymer ratios for fast, moderate, and slow release profiles are 35:65, 25:75, and 8.8:91.2, respectively, with varying degrees of drug release over time (Acharya and Park, 2006). The long-term retention of paclitaxel within the stent has raised concerns over delayed healing or hypersensitivities that may contribute to the development of very late stent thrombosis (Joner et al., 2006).

The first-in-man trial evaluating a PES was the TAXUS I trial that compared TAXUS NIR PES to the bare-metal stent (BMS) counterpart. TAXUS I was designed as a multicenter RCT that enrolled approximately 61 patients and had a primary endpoint of major adverse cardiac events (MACE) at 30 days follow-up. Patients were randomized 1:1 to receive a single $12 \mathrm{~mm}$ long TAXUS-SR PES or BMS in de novo coronary vessels measuring 3.0-3.5 $\mathrm{mm}$ diameter (Halkin and Stone, 2004). Although the study was designed primarily to evaluate safety, the low late loss and neointimal hyperplasia in the TAXUS arm suggested benefits of this DES when compared to the BMS counterpart similarly observed in the RAVEL and SIRIUS trials. At 30 days, there was no difference observed in MACE rates, as both the TAXUS and the BMS arms had no events and numerically low rates persisted at one year in favor of the TAXUS NIR arm respectively, 3.0\% versus 10.0\% (Colombo et al., 2003; Grube et al., 2003). At six months, the in-stent LL in the TAXUS NIR arm was $0.36 \pm 48$ mm compared to $0.71 \pm 0.47 \mathrm{~mm}$ in the BMS arm ( $\mathrm{p}$ value $=0.008)$ and the neointimal hyperplasia volume was $14.8 \pm 10.8$ compared to $21.6 \pm 10.7 \mathrm{~mm}^{3}$ ( $\mathrm{p}$ value $=0.028$ ), respectively (Halkin and Stone, 2004). The TAXUS II trial was also designed as a multicenter RCT but expanded enrollment to approximately 536 patients that were randomized to either TAXUS SR $(n=131)$, TAXUS MR (135), or the NIR BMS $(n=134)$ counterpart. The primary endpoint was \% in-stent volume obstruction at 6 months and was statistically significant in favor of the TAXUS SR and TAXUS MR patients compared to the BMS treated patients ( $\mathrm{p}<0.001$ ) (Colombo et al., 2003). The in-stent LL and TLR rates continued to favor the TAXUS SR and MR treated patients through long-term follow-up as well with no late thrombosis events occurring between two and three year follow-up in the DES treated patients.

The feasibility to treat patients with in-stent restenosis was explored in TAXUS III which was designed as an uncontrolled, single-arm, multicenter pilot study. The trial enrolled 28 patients treated with TAXUS PES for in-stent restenosis following previous BMS treatment and was further explored in the TAXUS V-ISR trial, which enrolled 396 patients and compared TAXUS PES (195 patients) to balloon angioplasty followed by vascular brachytherapy (201 patients) (Stone et al., 2006; Tanabe et al., 2003). The results supported the safety and efficacy of TAXUS PES compared to vascular brachytherapy, with numerically lower rates of stent thrombosis, MACE, MI, and TLRs compared to the BMS arm (Lasala et al., 2006). 
TAXUS IV was designed as randomized, controlled, multicenter trial that enrolled approximately 1,314 patients in the U.S for the treatment of single vessel disease with de novo coronary lesions. The primary endpoint was TVR at 9 months and compared the TAXUS Express PES to BMS in patients with reference vessel diameter (RVD) of 2.5 -3.75 $\mathrm{mm}$ and de novo lesions measuring $10-28 \mathrm{~mm}$ in length to be coverable by a single stent (Halkin and Stone, 2004). The baseline characteristics were notably well matched between the DES and the BMS arm, as the mean RVD and lesion lengths were the same in both arms, respectively $2.75 \mathrm{~mm}$ and $13.4 \mathrm{~mm}$. At 9 months, statistically significant differences were noted between the TAXUS DES and BMS in the primary endpoint, as well as for MACE and TLR. The primary endpoint results for TVR at 9 months was $8.5 \%$ in the TAXUS DES arm compared to $15.0 \%$ in the BMS arm ( $\mathrm{p}=0.0002)$, as well as showing significance in TLR at 9 months (Halkin and Stone, 2004). The TLR rates were statistically significant at 9 months in favor of the TAXUS DES arm in patients with orally medicated treated diabetes $(p<0.0001)$ and non-diabetes $(p<0.0001)$, with the exception of patients with insulin treated diabetes $(p=0.32)$ (Halkin and Stone, 2004). For the safety endpoints of death, MI, and stent thrombosis (ST) were non-significant at 9 months in the overall population and suggested that clinical safety was not compromised in exchange for more efficacy with the use of DES.

To further evaluate the TAXUS Express PES in more complex patient populations, the TAXUS V and TAXUS VI clinical trials aimed to evaluate results when compared to BMS. The TAXUS V clinical trial was a randomized, multicenter trial that enrolled 1156 patients with de novo lesions measuring $10-46 \mathrm{~mm}$ in length in reference vessel diameters between $2.25-4.0 \mathrm{~mm}$; a minimum of 200 patients each with a $2.25 \mathrm{~mm}$ diameter or a $4.0 \mathrm{~mm}$ diameter were enrolled, as well as a minimum of 300 patients with overlapping stents (Halkin and Stone, 2004). The rates of the primary endpoint of TVR at 9 months were higher in the DES arm than previously observed in the earlier trials, yet still demonstrated a statistically significant difference compared to the BMS arm at 9 months ( $p=0.0184$ ) (Stone et al., 2005). TAXUS VI trial was designed to evaluate the performance of TAXUS Express compared to BMS and was a multicenter, randomized controlled trial with a primary endpoint of TVR at 9 months and enrolled 446 patients. The results of the primary endpoint revealed that TAXUS Express TVR rates at 9 months were numerically lower than the TAXUS Express rates from the TAXUS V trial, but both continued to outperform the BMS counterpart in reducing revascularization events (Dawkins et al., 2005). Following approval of the TAXUS Express, the ARRIVE I and II post-market surveillance registries were initiated to continue to monitor safety in 'real-world' setting patients that receive treatment with the TAXUS Express. Patients enrolled in the postmarket registries or all-comer trials may not have been eligible in the previous RCTs that have specific inclusion and exclusion criteria, and thus may give a broader perspective of how the stent performs in real clinical practice with more complex patient and lesion subsets. The ARRIVE-1 was the first post-market registry for TAXUS and enrolled over 2000 patients and the ARRIVE-II registry enrolled over 4,000 patients (Dobies, 2007; Lasala et al., 2006). Boston Scientific pooled the data from these registries and was able to show that TAXUS was used in patient populations more complex than previously evaluated in the RCTs, such as bifurcation lesions, acute myocardial infarction, and ostial lesions (Lasala et al., 2006). 


\begin{tabular}{|c|c|c|c|c|c|c|}
\hline Trial & Design & $\begin{array}{c}\text { Sample } \\
\text { size }\end{array}$ & $\begin{array}{l}\text { Primary } \\
\text { endpoint }\end{array}$ & $\begin{array}{c}\text { PES } \\
\text { treatment } \\
\text { arm }\end{array}$ & $\begin{array}{c}\text { BMS } \\
\text { treatment } \\
\text { arm }\end{array}$ & P value \\
\hline TAXUS I & $\begin{array}{c}\text { Randomized } \\
\text { multicenter }\end{array}$ & 61 & $\begin{array}{c}\text { MACE at } 30 \\
\text { days }\end{array}$ & $0.0 \%$ & $0.0 \%$ & $\begin{array}{c}\text { Not } \\
\text { significant } \\
\text { (under } \\
\text { powered) }\end{array}$ \\
\hline TAXUS II & $\begin{array}{c}\text { Randomized, } \\
\text { multicenter }\end{array}$ & 536 & $\begin{array}{l}\% \text { in-stent } \\
\text { volume } \\
\text { obstruction } \\
\text { at } 6 \text { months }\end{array}$ & $\begin{array}{l}\text { SR 7.9\% } \\
\text { MR 7.8\% }\end{array}$ & $\begin{array}{l}23.2 \% \\
20.5 \%\end{array}$ & $\begin{array}{l}P<0.001 \\
P<0.001\end{array}$ \\
\hline TAXUS IV & $\begin{array}{c}\text { Randomized } \\
\text { multicenter }\end{array}$ & 1,314 & $\begin{array}{l}\text { TVR at } 9 \\
\text { months }\end{array}$ & $4.7 \%$ & $11.3 \%$ & $\mathrm{P}<0.001$ \\
\hline TAXUS V & $\begin{array}{c}\text { Randomized } \\
\text { multicenter }\end{array}$ & 1,156 & $\begin{array}{l}\text { TVR at } 9 \\
\text { months }\end{array}$ & $12.1 \%$ & $17.3 \%$ & $P=0.0184$ \\
\hline TAXUS VI & $\begin{array}{c}\text { Randomized, } \\
\text { multicenter }\end{array}$ & 446 & $\begin{array}{l}\text { TVR at } 9 \\
\text { months }\end{array}$ & $9.1 \%$ & $19.4 \%$ & $P=0.0027$ \\
\hline $\begin{array}{l}\text { ARRIVE I \& } \\
\text { II } \\
\text { Pooled post- } \\
\text { marketing } \\
\text { surveillance }\end{array}$ & $\begin{array}{l}\text { Open label, } \\
\text { single arm, } \\
\text { multicenter }\end{array}$ & 7,492 & $\begin{array}{c}\text { TAXUS } \\
\text { stent } \\
\text { related } \\
\text { cardiac } \\
\text { events at } 1 \\
\text { year }\end{array}$ & $9.5 \%$ & $\begin{array}{c}\text { Not } \\
\text { applicable }\end{array}$ & $\begin{array}{c}\text { Not } \\
\text { applicable }\end{array}$ \\
\hline
\end{tabular}

Table 2. Clinical trials evaluating TAXUS paclitaxel-eluting stents

The next generation of TAXUS stent was the TAXUS Liberte PES evaluated in the ATLAS program and was conducted similarly to the TAXUS Express program, with an ATLAS de novo, ATLAS expansion, and OLYMPIA registry. These trials evaluated unmet needs in DES and aimed to expand the indications for use in these more complex lesion and patients. The TAXUS Liberte stent was approved for commercialization in the U.S by the FDA on April 12, 2005 and uses the same open-cell design, Translute polymer, and paclitaxel drug as the TAXUS Express system yet has thinner polymer $(17 \mu \mathrm{m})$ and thinner struts $(97 \mu \mathrm{m})$. The ATLAS trial was a single-arm, multicenter trial that used a historical control group with matched lesions from the TAXUS IV and V clinical trials. The primary endpoint was noninferiority compared to the historic control group in terms of TVR at 9 months. The TAXUS Liberte stent demonstrated non-inferiority compared to the historic control, despite having more complex patients evaluated in the TAXUS Liberte arm (Turco, 2008). The ATLAS 
program expanded to evaluate small vessel and long lesion treatment with the TAXUS Liberté stent in the ATLAS Small Vessel $2.25 \mathrm{~mm}$ and ATLAS Long Lesion clinical trials (Table 3).

\begin{tabular}{|c|c|c|c|c|c|c|}
\hline Trial & Design & $\begin{array}{c}\text { Sample } \\
\text { size }\end{array}$ & $\begin{array}{l}\text { Primary } \\
\text { endpoint }\end{array}$ & $\begin{array}{c}\text { PES } \\
\text { treatment } \\
\text { arm }\end{array}$ & $\begin{array}{c}\text { Comparator } \\
\text { arm }\end{array}$ & $P$ value \\
\hline $\begin{array}{l}\text { TAXUS } \\
\text { ATLAS } \\
\text { (TAXUS } \\
\text { Liberté) }\end{array}$ & $\begin{array}{c}\text { Single arm } \\
\text { compared to } \\
\text { historical } \\
\text { TAXUS IV and } \\
\text { V PES control } \\
\text { group, } \\
\text { multicenter }\end{array}$ & 871 & $\begin{array}{l}\text { TVR at } 9 \\
\text { months }\end{array}$ & $7.95 \%$ & $7.01 \%$ & $\begin{array}{c}\text { P non- } \\
\text { inferiority = } \\
0.0487\end{array}$ \\
\hline $\begin{array}{c}\text { TAXUS } \\
\text { Liberté } \\
\text { ATOM - } \\
\text { ATLAS } \\
\text { Small Vessel } \\
\text { (Expansion) } \\
\end{array}$ & $\begin{array}{c}\text { Single arm } \\
\text { compared to } \\
\text { DES and BMS, } \\
\text { multicenter }\end{array}$ & 261 & $\begin{array}{c}\% \\
\text { Diameter } \\
\text { stenosis at } \\
9 \text { months }\end{array}$ & $32.2 \%$ & $\begin{array}{l}\text { PES 39.6\% } \\
\text { BMS 40.1\% }\end{array}$ & $p<0.0001$ \\
\hline $\begin{array}{c}\text { TAXUS } \\
\text { ATLAS Long } \\
\text { Lesion }\end{array}$ & $\begin{array}{c}\text { Single arm } \\
\text { compared to } \\
\text { historical } \\
\text { TAXUS IV and } \\
\text { V PES control } \\
\text { group, } \\
\text { multicenter }\end{array}$ & 150 & $\begin{array}{c}\% \\
\text { Diameter } \\
\text { stenosis at } \\
9 \text { months }\end{array}$ & $31.4 \%$ & $35.5 \%$ & $p<0.0001$ \\
\hline $\begin{array}{c}\text { ION - } \\
\text { PERSEUS }\end{array}$ & $\begin{array}{c}\text { Randomized, } \\
\text { multicenter } \\
\text { compared to } \\
\text { TAXUS } \\
\text { Express } \\
\end{array}$ & 1264 & $\begin{array}{c}\text { TLF at } 12 \\
\text { months }\end{array}$ & $5.6 \%$ & $6.1 \%$ & $p=0.003$ \\
\hline $\begin{array}{c}\text { ION - } \\
\text { Small Vessel }\end{array}$ & $\begin{array}{l}\text { Open label, } \\
\text { single arm, } \\
\text { compared to } \\
\text { BMS }\end{array}$ & 224 & $\begin{array}{c}\text { In-stent } \\
\text { late loss at } \\
9 \text { months }\end{array}$ & $0.38 \pm 0.51$ & $0.80 \pm 0.53$ & $p<0.0001$ \\
\hline
\end{tabular}

Accessed at http://www.bostonscientific.com/templatedata/imports/collateral/eDFU/

Table 3. Clinical trials evaluating TAXUS Liberté and ION Element stents

The most recent generation of DES developed by Boston Scientific, the Platinum Element ION PES (ION), has additional design changes from the TAXUS Liberte that aim to further improve patient outcomes. Studies have suggested that various alloys provide different 
strength and allow for thinner struts that subsequently enhance healing and may reduce revascularizations (Ako et al., 2007; Joner et al., 2008; Kastrati et al., 2001). The Platinum ION PES system was approved by the FDA on April 22, 2011 as the latest generation of DES and utilizes a platinum chromium alloy stent but uses the same polymer and drug as the TAXUS Express with the same concentration $\left(1 \mu \mathrm{g} / \mathrm{mm}^{2}\right)$. The improved design offers thinner struts $(81 \mu \mathrm{m})$ and thin polymer layer $(14.9 \mu \mathrm{m})$. The ION stent system has been evaluated in the PERSEUS clinical trial for the treatment of de novo coronary lesions of $\leq 28 \mathrm{~mm}$ length in vessels measuring between $2.75-4.0 \mathrm{~mm}$. The PERSEUS clinical trial is a randomized controlled trial comparing the ION stent system to the TAXUS Express stent and has a primary endpoint of target lesion failure (TLF) at 12 months. The primary endpoint was met and the ION stent demonstrated non-inferiority compared to the well established TAXUS Express stent in terms of TLF at 12 months. The ION stent has also been evaluated in vessel sizes $\geq 2.25$ and $<2.75 \mathrm{~mm}$ diameter and lesion lengths $\leq 20 \mathrm{~mm}$ in the ION Small Vessel trial versus the performance of BMS from TAXUS IV and V historical comparator arms (Table 3). The primary endpoint was in-stent late loss at 9 months and superiority ( $\mathrm{p}<$ 0.0001) was met compared to the BMS control arm and furthermore, ION has also demonstrated comparable results to the TAXUS Liberté stent (Meredith, 2011). From the first generation TAXUS NIR to the Platinum ION systems, the PES clinical trial program established safety and efficacy for the treatment of coronary artery lesions. Boston Scientific has also developed a drug-eluting stent with a biodegradable polymer, the JACTAX ${ }^{\mathrm{TM}}$ PES further discussed in section 8. In addition, the XIENCE V stent is also distributed as the PROMUS everolimus-eluting stent (EES) by Boston Scientific noted in Section 5.

\section{ENDEAVOR ${ }^{\circledR}$ and RESOLUTE ${ }^{\mathrm{TM}}$}

The Endeavor zotarolimus-eluting stent system (ZES) is the first DES manufactured by Medtronic, Inc., Santa Rosa, CA. The stent received FDA approval for commercialization in the U.S in February, 2008. The Endeavor DES utilizes the Driver BMS cobalt alloy stent and a phosphorylcholine lipophilic (PC) polymer coating outside of the stent for delivery of zotarolimus, which is an anti-proliferative drug eluted within 14 days and faster than the first generation DES. Another DES that utilizes zotarolimus was the ZoMaxx stent system manufactured by Abbott Vascular and became commercially available outside of the U.S. Zotarolimus is a highly lipophilic anti-proliferative drug that rapidly is dissolved and has been found to inhibit neointimal hyperplasia (Garcia-Touchard et al., 2006). The thin strut design $(91 \mu \mathrm{m})$ with the added benefit of rapid drug elution allows for rapid endothelialization, reduced inflammation and the promotion of healing.

The Endeavor ZES was first studied in the Endeavor I single-arm, multicenter clinical trial and enrolled 100 patients with de novo coronary lesions measuring $\leq 15 \mathrm{~mm}$ in length in vessels with diameter sizes between 3.0-3.5 mm. The primary efficacy endpoint was in-stent late loss at 4 months and was $0.33 \pm 0.36 \mathrm{~mm}$ and the primary safety endpoint was MACE at 30 days and was 1.0\% for the Endeavor ZES (Meredith et al., 2005). The Endeavor II clinical trial enrolled 1,197 patients and was a randomized multicenter trial comparing Endeavor ZES to the Driver BMS for treatment of single de novo lesion measuring $>14 \mathrm{~mm}$ and $\leq 27$ $\mathrm{mm}$ in vessel diameters between $2.25-3.5 \mathrm{~mm}$. The primary endpoint was TVF at 9 months and the Endeavor arm (7.9\%) demonstrated non-inferiority to the Driver BMS arm (15.1\%) at 9 months $(p=0.0001)$ (Fajadet et al., 2006). The Endeavor II clinical trial was extended as a 
continued access trial (Endeavor II CA) and enrolled 296 additional patients in a single arm allowing single lesion treatment $<20 \mathrm{~mm}$ in vessel sizes $2.25-3.5 \mathrm{~mm}$.

The Endeavor III randomized multi-center trial enrolled 436 patients (3:1) comparing the Endeavor ZES to Cypher SES for single de novo lesion treatment measuring $>14 \mathrm{~mm}$ and $\leq$ $27 \mathrm{~mm}$ in vessel diameters between $2.25-3.5 \mathrm{~mm}$. The primary endpoint was in-segment late loss at 8 months and the Endeavor arm demonstrated numerically higher late loss (0.34 $\pm 0.44 \mathrm{~mm}$ ) compared to the Cypher SES arm $(0.13 \pm 0.32)$ (Kandzari et al., 2006). Endeavor IV was the pivotal randomized clinical trial that enrolled 1,548 patients with a single de novo lesion measuring $\leq 27 \mathrm{~mm}$ in vessels measuring $2.5 \mathrm{~mm}-3.5 \mathrm{~mm}$, thus restricting the small vessel sizes that had previously been evaluated in Endeavor I, II, and III. The trial had a clinical composite endpoint of target vessel failure (TVF; defined as cardiovascular death, MI, and target vessel revascularization) at 9 months and also included angiographic and IVUS endpoints. The primary endpoint was met and the Endeavor stent demonstrated noninferiority compared to the TAXUS Express PES at 9 months respectively, $(6.6 \%$ versus $7.1 \%$, $\mathrm{p}<0.001$ ), (Leon et al., 2010). Based on the results from the Endeavor II, III, and IV, it was evident that the Endeavor stent outperformed the Driver BMS in terms of reducing TLR, but the same outcome was not observed when compared to the current gold standard first generation stents (CYPHER and TAXUS). In the Endeavor III trial, the Endeavor arm had numerically higher late loss and TLR rates compared to the CYPHER arm, respectively (6.3\% versus 3.5\%) (Maeng et al., 2010). In the Endeavor IV trial, the Endeavor arm also had numerically higher TLR rates compared to the TAXUS arm through the 3 year follow-up, respectively $(6.5 \%$ versus $6.0 \%)$ not showing improved efficacy over the first generation DES, which was expected with a next generation DES (Leon et al., 2009). Subsequently, a new DES, known as the RESOLUTETM ZES was developed by Medtronic to improve upon the Endeavor stent (Maeng et al., 2010).

The RESOLUTE ZES is the newest generation of DES developed by Medtronic currently under evaluation in randomized and all-comer trials that will be seeking FDA approval for commercialization in the U.S. in April, 2011 and has already received C.E. Mark status for outside of the U.S. in 2007. The RESOLUTE ZES utilizes the same stent as in DRIVER and ENDEAVOR and zotarolimus, but uses the BioLinx polymer outside coating for extended release of zotarolimus (Leon, 2011). The RESOLUTE first-in-man trial was a single-arm multicenter trial that enrolled 139 patients and evaluated in-stent late loss compared to the ENDEAVOR ZES matched cohort from Endeavor II. The late loss was reduced by $0.39 \mathrm{~mm}$ $(p<0.001)$ with the RESOLUTE stent and the TLR rate was $1.0 \%$ at 1 year, suggesting that delayed elution through the RESOLUTE stent design may translate to improved safety and efficacy (Meredith et al., 2009).

The RESOLUTE All-Comers (RAC) trial was the first trial to compare RESOLUTE ZES to the next generation XIENCE V everolimus-eluting stent (EES) manufactured by Abbott Vascular (refer to section 5). The RAC trial is a randomized, open-label, multicenter investigation comparing 2,292 patients randomized 1:1 to RESOLUTE ZES or XIENCE V EES with a primary endpoint of target lesions failure (TLF; defined as cardiac death, target vessel MI, and target lesion revascularization) at 1 year. The RESOLUTE ZES was found to be noninferior to the XIENCE V EES at 1 year. The RESOLUTE ZES arm TLF rate at 1 year was $8.2 \%$ and the XIENCE V EES rate was $8.3 \%$ ( $p=$ non-inferiority) (Meredith, 2011). The trial evaluated notably more complex patient and lesion types than in the previous ENDEAVOR 
or RESOLUTE trials where inclusion and exclusion criteria restricted more challenging cases. Clinical outcomes remained comparable overall through two years between treatment arms for death, MI, TLR, and ST events (Meredith, 2011).

\begin{tabular}{|c|c|c|c|c|c|c|}
\hline Trial & Design & $\begin{array}{l}\text { Sample } \\
\text { size }\end{array}$ & $\begin{array}{l}\text { Primary } \\
\text { endpoint }\end{array}$ & $\begin{array}{c}\text { ZES } \\
\text { treatment } \\
\text { arm }\end{array}$ & $\begin{array}{c}\text { Comparator } \\
\text { arm }\end{array}$ & $P$ value \\
\hline Endeavor I & $\begin{array}{l}\text { Single-arm, } \\
\text { multicenter }\end{array}$ & 100 & $\begin{array}{c}\text { MACE at } \\
30 \text { days; } \\
\text { in-stent } \\
\text { LL at } 120 \\
\text { days }\end{array}$ & $\begin{array}{c}\text { MACE 1\%; } \\
\text { in-stent LL } \\
0.33 \pm 0.36 \\
\text { mm }\end{array}$ & $\begin{array}{c}\text { Not } \\
\text { applicable }\end{array}$ & $\begin{array}{c}\text { Not } \\
\text { applicable }\end{array}$ \\
\hline Endeavor II & $\begin{array}{c}\text { Randomized, } \\
\text { multicenter }\end{array}$ & 1,197 & $\begin{array}{l}\text { TVF at } 9 \\
\text { months }\end{array}$ & $7.9 \%$ & Driver $15.1 \%$ & $\mathrm{P}=0.0001$ \\
\hline $\begin{array}{c}\text { Endeavor } \\
\text { III }\end{array}$ & $\begin{array}{l}\text { Randomized, } \\
\text { multicenter }\end{array}$ & 436 & $\begin{array}{l}\text { In- } \\
\text { segment } \\
\text { late loss at } \\
8 \text { months }\end{array}$ & $\begin{array}{c}0.34 \pm 0.44 \\
\mathrm{~mm}\end{array}$ & $\begin{array}{c}\text { CYPHER } \\
0.13 \pm 0.32 \\
\mathrm{~mm}\end{array}$ & $\mathrm{P}<0.001$ \\
\hline $\begin{array}{l}\text { Endeavor } \\
\text { IV }\end{array}$ & $\begin{array}{c}\text { Randomized, } \\
\text { multicenter }\end{array}$ & 1,548 & $\begin{array}{l}\text { TVF at } 9 \\
\text { months }\end{array}$ & $6.6 \%$ & TAXUS 7.1\% & $\mathrm{P}<0.001$ \\
\hline RESOLUTE & $\begin{array}{l}\text { Single-arm, } \\
\text { multicenter, } \\
\text { feasibility }\end{array}$ & 139 & $\begin{array}{c}\text { In-stent } \\
\text { late loss at } \\
9 \text { months }\end{array}$ & $\begin{array}{c}0.22 \pm 0.27 \\
\mathrm{~mm}\end{array}$ & $\begin{array}{c}\text { ENDEAVOR } \\
\text { II (matched } \\
\text { cohort) } 0.62 \\
\pm 0.46 \mathrm{~mm} \\
\end{array}$ & $\mathrm{P}<0.001$ \\
\hline $\begin{array}{c}\text { RESOLUTE } \\
\text { All-Comers } \\
\text { (RAC) }\end{array}$ & $\begin{array}{c}\text { Randomized, } \\
\text { multicenter }\end{array}$ & 2,292 & $\begin{array}{c}\text { TLF at } 1 \\
\text { year }\end{array}$ & $8.2 \%$ & $\begin{array}{c}\text { XIENCE V } \\
8.3 \%\end{array}$ & $\mathrm{P}<0.001$ \\
\hline $\begin{array}{l}\text { RESOLUTE } \\
\text { U.S. }\end{array}$ & $\begin{array}{l}\text { Single-arm, } \\
\text { multicenter }\end{array}$ & 1,402 & $\begin{array}{c}\text { TLF at } 1 \\
\text { year }\end{array}$ & $3.7 \%$ & $\begin{array}{c}\text { ENDEAVOR } \\
\text { (historical) } \\
6.5 \%\end{array}$ & $\begin{array}{c}P \sup = \\
0.002\end{array}$ \\
\hline
\end{tabular}

Table 4. Clinical trials evaluating the ENDEAVOR and RESOLUTE zotarolimus eluting stents

A RESOLUTE U.S. trial is being conducted with 1402 patients in the RESOLUTE stent arm and is a single-arm, multicenter trial using Endeavor historical data as a comparator arm to evaluate the primary endpoint of target lesion failure (TLF; defined as cardiac death, target vessel MI, and target lesions revascularization) at 1 year. The RESOLUTE U.S. trial design allowed for $2.25-4.2 \mathrm{~mm}$ vessel diameter and lesion length $\leq 27 \mathrm{~mm}$ (Yeung et al., 2011). The trial evaluated for non-inferiority and superiority using a performance goal from the Endeavor program and was able to demonstrate both non-inferiority and superiority at 1 year in terms of TLF. At 1 year, the RESOLUTE arm main cohort showed a $3.7 \%$ rate of TLF 
compared to $6.5 \%$ from the Endeavor historical control arm (p non-infer. $<0.001$ and $\mathrm{p}$ sup $=$ 0.002) (Leon, 2011). The numerically lower rates of TLF observed in the RESOLUTE arm compared to the historical Endeavor arm may be attributed to change in polymer (BioLinx) with subsequent extended release of zotarolimus. The RESOLUTE clinical trial program continues to follow patient outcomes for long-term follow-up and has also multiple trials currently underway OUS, such as the RESOLUTE International, the RESOLUTE Japan, RESOLUTE ASIA, and RESOLUTE CHINA.

\section{XIENCE $V^{\circledR}$ and XIENCE PRIME ${ }^{\mathrm{TM}}$}

The XIENCE V everolimus-eluting stent (EES) was approved by the FDA on July 2, 2008 and is manufactured by Abbott Vascular. The XIENCE V stent/scaffold is the MULTILINK VISION bare metal stent and it is the thinnest strut platform of the DES approved for commercialization in the US to date. Compared to CYPHER $(140 \mu \mathrm{m})$, TAXUS EXPRESS $(132 \mu \mathrm{m})$, TAXUS Liberte $(97 \mu \mathrm{m})$, and ENDEAVOR $(91 \mu \mathrm{m})$, the XIENCE V $(81 \mu \mathrm{m})$ strut remains the thinnest for first and second generation DES in the USA and is comparable to the Platinum Chromium Element stent $(81 \mu \mathrm{m})$ (Smits, TCT 2009). XIENCE V uses an acrylic polymer primer coating outside of the stent, referred to as PBMA [poly (nbutylmethacrylate)], covered by a fluorinated copolymer coating made of two monomeric compounds (vinylidene fluoride and hexafluoropropylene). XIENCE V was engineered to elute everolimus from a thin (7.8 micron), non adhesive, durable, biocompatible, and fluorinated copolymer (Bezenek et al., 2011). Everolimus is an anti-proliferative drug with anti-inflammatory properties that arrests the cell in the G1 phase. The XIENCE V EES clinical trial program has established a robust body of data. The SPIRIT FIRST study was a first-in-man, multi-center, randomized, controlled trial conducted in Europe to assess the feasibility and performance of the XIENCE V in the treatment of subjects with a single de novo native coronary artery lesion compared to the metallic, uncoated MULTI LINK VISION RX Coronary Stent System (VISION RX CSS). SPIRIT FIRST enrolled approximately 60 patients with reference vessel size of $3 \mathrm{~mm}$ and a single lesion length $\leq 12 \mathrm{~mm}$. The primary endpoint was in-stent late loss at 6 months and XIENCE V demonstrated superiority to the MULTI-LINK VISION BMS arm by meeting the primary endpoint with $0.10 \pm 0.23 \mathrm{~mm}$ late loss compared to the BMS arm late loss of $0.85 \pm 0.36 \mathrm{~mm}$ (superiority $P$ value $<0.0001)$. The trial was designed with a major secondary endpoint of $\%$ volume obstruction (\%VO) and the XIENCE $\mathrm{V}$ arm demonstrated a $72 \%$ reduction in \%VO compared to the BMS arm, respectively $(8.0 \%$ versus $21.0 \%, p<0.001)$. The trial has completed 5 year follow-up and notably, there was no stent thrombosis event reported in either arm in the SPIRIT FIRST study. Safety and efficacy results evident in the SPIRIT FIRST trial led to the SPIRIT II trial.

The SPIRIT II trial was a multi-center randomized trial (3:1) designed to continue assessing the safety and performance of the XIENCE V in the treatment of patients with a maximum of two de novo native coronary artery lesions each in a different epicardial vessel, compared to TAXUS. The SPIRIT II clinical study arm allowed the treatment of de novo lesions $\leq 28$ $\mathrm{mm}$ in length in coronary arteries with a reference vessel diameter (RVD) $\geq 2.5 \mathrm{~mm}$ to $\leq 4.25$ $\mathrm{mm}$. Three hundred (300) patients were enrolled in the study; 223 patients were treated with XIENCE V, 59 patients were treated with TAXUS EXPRESS, and 17 patients received TAXUS Liberté. The primary endpoint was in-stent late loss at 6 months and was designed 
with angiographic and IVUS endpoints. The trial was powered for a major secondary endpoint of in-segment late loss as well. XIENCE $V^{\circledR}$ demonstrated non-inferiority to the TAXUS ${ }^{\circledR}$ arm in terms of the primary endpoint of in-stent late loss. The XIENCE V arm was $0.11 \pm 0.27 \mathrm{~mm}$ compared to $0.36 \pm 0.39 \mathrm{~mm}$ in the TAXUS arm $(\mathrm{p}<0.0001)$. The primary endpoint demonstrated that XIENCE $V^{\circledR}$ was statistically superior to the TAXUS ${ }^{\circledR}$ (superiority P value < 0.0001). The in-segment late loss results favored the XIENCE V arm compared to the TAXUS arm with a 53\% reduction observed at 6 months. The clinical follow-up through 5 years supported the safety and efficacy of the XIENCE V EES and no late catch-up was observed.

The SPIRIT III pivotal clinical trial was designed to demonstrate the non-inferiority of XIENCE V to TAXUS. Conducted in the United States (US) and Japan, the SPIRIT III clinical trial was composed of a randomized clinical trial in the US (RCT) and a non-randomized arm (4.0 $\mathrm{mm}$ arm) and one non-randomized arm in Japan. The SPIRIT III RCT was designed as a randomized (2:1), multi-center non-inferiority evaluation of the XIENCE V stent compared to the TAXUS stent and enrolled a total of 1002 patients (669 patients in XIENCE $\mathrm{V}$ arm and 333 patients in the TAXUS arm). Treatment of up to two de novo lesions $\leq 28 \mathrm{~mm}$ in length in native coronary arteries with RVD $\geq 2.5 \mathrm{~mm}$ to $\leq 3.75 \mathrm{~mm}$ was permitted. The trial design had a primary efficacy endpoint of in-segment late loss at 8 months and also a coprimary endpoint of TVF at 9 months. In the SPIRIT III RCT arm, XIENCE V was found to be statistically non-inferior to TAXUS (Stone, 2010). The primary endpoint of in-segment LL at 8 months results for the XIENCE V arm was $0.14 \pm 41 \mathrm{~mm}$ and for the TAXUS arm was $0.28 \mathrm{~mm}$ $\pm 48 \mathrm{~mm}$ (p non-inferior < 0.0001). Additionally, since non-inferiority was demonstrated, a superiority analysis of the primary endpoint was performed using a two-sided t-test with alpha $=0.05$. The analysis showed the superiority of XIENCE V to the TAXUS arm in terms of the primary endpoint of in-segment LL at 8 months ( $p$ superior $=0.0037$ ). The major secondary endpoint of TVF was also met with the XIENCE V arm demonstrating numerically lower rates $(7.6 \%)$ compared to the TAXUS arm $(9.7 \%)$ at 9 months (p non-inferior $<0.0001)$.

As part of the SPIRIT III clinical trial design, the non-randomized $4.0 \mathrm{~mm}$ arm was compared to the TAXUS patients of the RCT arm. The SPIRIT III $4.0 \mathrm{~mm}$ arm trial demonstrated consistent results with the SPIRIT III RCT arm. The SPIRIT III $4.0 \mathrm{~mm}$ nonrandomized arm demonstrated non-inferiority of XIENCE V $4.0 \mathrm{~mm}$ arm compared to the TAXUS RCT arm in terms of the primary endpoint of in-segment LL at 8 months ( $p$ noninferior < 0.0001). In-segment LL at 8 months was $0.17 \pm 0.38 \mathrm{~mm}$ for the XIENCE V $4.0 \mathrm{~mm}$ arm and $0.28 \pm 0.48 \mathrm{~mm}$ for the TAXUS RCT arm. The third cohort of the SPIRIT III trial that actively enrolled patients was the SPIRIT III Japan single-arm trial. In the SPIRIT III Japan arm, the XIENCE V arm was also found to be statistically non-inferior to TAXUS RCT arm. The primary endpoint of the trial was met with in-segment LL results of $0.15 \pm 0.34 \mathrm{~mm}$ for the XIENCE V Japan arm and $0.28 \pm 0.48 \mathrm{~mm}$ for the TAXUS RCT arm at 8 months. The XIENCE V Japan arm also demonstrated non-inferiority to the TAXUS RCT arm for insegment LL at 8 months ( $p$ non-inferior $<0.0001$ ). No stent thrombosis occurred through two-year follow-up in the XIENCE V Japan arm. Clinical results of treatment with XIENCE $\mathrm{V}$ in the SPIRIT III trial supported the safety and efficacy of XIENCE V and since approval in the U.S., has demonstrated long-term follow-up with 5 year results available this year at TCT 2011. In order to expand XIENCE V use to more complex patients, the SPIRIT IV clinical trial was designed to allow for multiple lesions to be treated beyond what was previously evaluated in earlier randomized trials for comparing DES. 
The SPIRIT IV clinical trial was a randomized (2:1) multi-center evaluation of the XIENCE V EES compared to the TAXUS PES in the treatment of up to three de novo lesions $\leq 28 \mathrm{~mm}$ in length in native coronary arteries with RVD $\geq 2.5 \mathrm{~mm}$ to $\leq 3.75 \mathrm{~mm}$. There were 3,687 patients enrolled and they were stratified based on diabetes mellitus status (diabetic vs. nondiabetic) and lesion characteristics (complex vs. non-complex). Complex lesion characteristics included triple vessel treatment, or dual lesions per vessel treatment, or lesions involving RCA-aorto-ostial locations, or bifurcations lesions. The primary endpoint was TLF at 1 year and two major secondary endpoints were also evaluated; TLR and the composite of target vessel MI and cardiac death at 1 year. In the SPIRIT IV clinical trial, XIENCE V demonstrated non-inferiority to TAXUS in terms of the primary endpoint of TLF respectively, $(4.2 \%$ compared to $6.8 \%$, p non-inferior $<0.0001$ ). Since non-inferiority was demonstrated, the prespecified superiority test of the primary endpoint was performed. Superiority of XIENCE V over TAXUS for the primary endpoint ( $p$ superior $=0.0012$ ) was also met at 1 year.

Additional pre-specified hypothesis tests for non-inferiority and superiority were performed for the major secondary endpoints of TLR and cardiac death or target vessel MI at 1 year. The XIENCE V arm demonstrated non-inferiority to the TAXUS arm in terms of TLR rates at 1 year, respectively $(2.5 \%$ and $4.6 \%$, p non-inferior $<0.0001)$. For cardiac death or target vessel MI, the XIENCE V arm also demonstrated non-inferiority to the TAXUS arm respectively, ( $2.2 \%$ compared to $3.2 \%, \mathrm{p}$ non-inferior < 0.0001). Moreover, the XIENCE V arm also demonstrated superiority ( $\mathrm{p}$ superior $=0.0012$ ) over the TAXUS arm for TLR, but did not meet superiority ( $\mathrm{p}$ superior $=0.0899$ ) for cardiac death or target vessel MI at 1 year. The SPIRIT IV trial showed numerically low ARC (definite/probable) ST rates through the two-year followup in the XIENCE V arm (0.42\%) compared to the TAXUS arm (1.23\%), consistent with earlier SPIRIT trials, but in a more complex patient population. A similar finding was observed in the all-comers, single arm post-marketing trial, the XIENCE V USA trial discussed here below.

The XIENCE V USA post-marketing safety and surveillance trial was designed as a singlearm, multicenter, open-label trial that enrolled 5,054 patients in the U.S following FDA approval of the XIENCE V EES in 2008. As part of the requirements for FDA approval, the XIENCE V USA evaluated the real-world usage of the XIENCE V EES in clinical practice and monitor safety outcomes. The primary endpoint is the composite of definite/probable ST rates as defined by the Academic Research Consortium (ARC) definitions and also has a co-primary endpoint of cardiac death and MI at 1 year and will follow patients through 5 year follow-up. As the trial is a post-approval study, the restrictions of inclusion and exclusion criteria do not limit the enrollment and thus provide a perspective of outcomes in patients that have not been evaluated in pivotal RCTs, such as AMI, in-stent restenosis, or chronic total occlusions. Despite having more complex subgroups, the XIENCE V patients have demonstrated consistent results at 1 year with ST rates comparable to the SPIRIT III pivotal trial, which only allowed for a single lesion per vessel treatment of less than $28 \mathrm{~mm}$. At 1 year, the XIENCE V USA ST rate was $0.8 \%$ and the cardiac death and MI rate was $6.3 \%$ (Hermiller, 2010).

More recently, the XIENCE V nano EES was approved by the FDA in May 2011 for the treatment of small vessels. The XIENCE V nano EES was approved as a line extension to the existing XIENCE V EES based on the results of the SPIRIT Small Vessel (SV) single-arm, multicenter clinical trial. The purpose of the SPIRIT SV trial was to evaluate the safety and efficacy of the $2.25 \mathrm{~mm}$ XIENCE V EES in improving coronary luminal diameter in subjects 
with symptomatic heart disease due to a maximum of two de novo native coronary artery lesions measuring $\leq 28 \mathrm{~mm}$ in small vessels ( $\geq 2.25 \mathrm{~mm}$ to $<2.50 \mathrm{~mm}$ ), each in a different epicardial vessel. The study was designed to enroll up to 150 patients with the first 60 patients enrolled in the angiographic cohort requiring angiographic follow-up at 8 months. The primary endpoint was TLF at 1 year and was required to meet a pre-specified performance goal of $20.4 \%$ at 1 year. The study was designed to enroll up to 150 patients with the first 60 patients enrolled in an angiographic cohort requiring angiographic followup at 8 months. The 1-year TLF rate was $8.1 \%$ and therefore met the performance goal of $20.4 \%$ and met the primary endpoint $(\mathrm{p}<0.0001)$. The mean in-segment late loss at 8 months was $0.16 \pm 0.41 \mathrm{~mm}$ and the mean in-stent late loss was $0.20 \pm 0.40 \mathrm{~mm}$, both slightly higher compared to the in-segment $(0.14 \pm 0.41 \mathrm{~mm})$ and in-stent late loss $(0.16 \pm 0.41 \mathrm{~mm})$ reported in the XIENCE V arm of SPIRIT III RCT, yet lower than the in-segment and in-stent late loss for SPIRIT III RCT TAXUS arm, respectively $(0.28 \pm 0.48 \mathrm{~mm}$ and $0.30 \pm 0.53 \mathrm{~mm})$.

\subsection{XIENCE PRIME TM}

As observed in the XIENCE V USA post-marketing single-arm trial, the complexity of patients and lesions being treated with DES is requiring more specialized treatments and challenging cases in the catheterization lab. In order to address this market need, the XIENCE PRIME and XIENCE PRIME Long Lesion (LL) EES were developed from the framework of the XIENCE V EES with modifications to further enhance deliverability, flexibility, and stent retention. The XIENCE PRIME utilizes an improved cobalt chromium alloy stent, but the same polymer composition of the poly n-butyl methacrylate (PBMA) primer coating, drug reservoir layer of poly vinylidene fluoride co-hexafluoropropylene (PVDF-HFP), and the same everolimus/polymer weight to weight combination ratio and thickness. XIENCE PRIME also uses the same anti-proliferative drug (everolimus) and has the same drug density $\left(100 \mu \mathrm{g} / \mathrm{cm}^{2}\right)$ as the original XIENCE V EES design. The strut thickness remains one of the thinnest available to date at $81 \mu \mathrm{m}$. Both the XIENCE V and the XEINCE PRIME were built upon the MULTI-LINK BMS design, but the XIENCE PRIME has the added features of the MULTI-LINK $8^{\mathrm{TM}}$ BMS design, where a link has been made taller and the cell has been lengthened. The delivery system also underwent important modifications that include a smooth rounded tip, designed to enhance tracking, and deliverability, while the shorter balloon taper aims to reduce stent injury.

The objective of the SPIRIT PRIME clinical trial is to evaluate the safety and effectiveness of the XIENCE PRIME ${ }^{\mathrm{TM}}$ and XIENCE PRIME LL ${ }^{\mathrm{TM}}$ EES in improving coronary luminal diameter in subjects with symptomatic heart disease. The XIENCE PRIME and XIENCE PRIME LL EES enrolled patients with symptomatic heart disease due to de novo native coronary artery lesions (lesion length $\leq 32 \mathrm{~mm}$ ) with vessel diameters measuring $\geq 2.25 \mathrm{~mm}$ and $\leq 4.25 \mathrm{~mm}$. The study was designed as a single-arm, open-label, multi-center nonrandomized clinical trial using the core size XIENCE PRIME and XIENCE PRIME LL. Approximately 500 subjects were enrolled; 400 in the Core Size Registry (CSR) and 100 in the Long Lesion Registry (LLR), which included stent lengths of 33 and $38 \mathrm{~mm}$. The primary endpoint of TLF at one year was required to meet pre-specified (per protocol) performance goals (PG); the CSR PG was 9.2\% and the PG for the LLR was 19.2\%. The XIENCE PRIME met the primary endpoint for both the CSR and the LLR in terms of TLF rates at 1 year with $6.5 \%$ for the CSR $(p=0.0038)$ and $12.5 \%$ for the LLR $(p=12.5 \%)$ as per ARC MI definition. 
Thus meeting the primary endpoint, the XIENCE PRIME Pre-Market Approval (PMA) packet has been submitted for FDA approval in April, 2011 by Abbott Vascular and is pending approval for commercialization in the U.S. XIENCE PRIME has already received C.E. Mark for commercialization in Europe since June, 2009. Long-term follow-up continues for XIENCE PRIME, Small Vessel, SPIRIT IV, and XIENCE V USA to further support the robust data supporting the safety and efficacy profile.

\begin{tabular}{|c|c|c|c|c|c|c|}
\hline Trial & Design & $\begin{array}{l}\text { Sample } \\
\text { size }\end{array}$ & $\begin{array}{l}\text { Primary } \\
\text { endpoint }\end{array}$ & $\begin{array}{c}\text { EES } \\
\text { treatment } \\
\text { arm }\end{array}$ & $\begin{array}{c}\text { Comparator } \\
\text { arm }\end{array}$ & $P$ value \\
\hline $\begin{array}{l}\text { SPIRIT } \\
\text { FIRST }\end{array}$ & $\begin{array}{c}\text { Randomized, } \\
\text { multicenter }\end{array}$ & 60 & $\begin{array}{c}\text { In-stent } \\
\text { late-loss at } \\
6 \text { months }\end{array}$ & $\begin{array}{c}0.10 \pm 0.23 \\
\mathrm{~mm}\end{array}$ & $\begin{array}{l}\text { BMS } 0.85 \\
\pm 0.36 \mathrm{~mm}\end{array}$ & $P<0.001$ \\
\hline SPIRIT II & $\begin{array}{c}\text { Randomized, } \\
\text { multicenter }\end{array}$ & 300 & $\begin{array}{c}\text { In-stent } \\
\text { late-loss at } \\
6 \text { months }\end{array}$ & $\begin{array}{c}0.11 \pm 0.27 \\
\mathrm{~mm}\end{array}$ & $\begin{array}{l}\text { TAXUS } 0.36 \\
\pm 0.39 \mathrm{~mm}\end{array}$ & $\mathrm{P}<0.0001$ \\
\hline SPIRIT III & $\begin{array}{c}\text { Randomized, } \\
\text { multicenter }\end{array}$ & 1,002 & $\begin{array}{l}\text { In-segment } \\
\text { late loss at } 8 \\
\text { months }\end{array}$ & $\begin{array}{c}0.14 \pm 0.41 \\
\mathrm{~mm}\end{array}$ & $\begin{array}{l}\text { TAXUS } 0.28 \\
\pm 0.48 \mathrm{~mm}\end{array}$ & $\begin{array}{l}P_{\text {superiority }} \\
\quad=0.004\end{array}$ \\
\hline SPIRIT IV & $\begin{array}{c}\text { Randomized, } \\
\text { multicenter }\end{array}$ & 3,687 & $\begin{array}{c}\text { TLF at } 1 \\
\text { year }\end{array}$ & $4.2 \%$ & $\begin{array}{c}\text { TAXUS } \\
6.8 \%\end{array}$ & $\begin{array}{l}P_{\text {superiority }} \\
\quad=0.001\end{array}$ \\
\hline $\begin{array}{l}\text { XIENCE } \\
\text { V USA }\end{array}$ & $\begin{array}{l}\text { Single-arm, } \\
\text { multicenter, } \\
\text { open label }\end{array}$ & 5,054 & $\begin{array}{l}\text { Composite } \\
\text { of Stent } \\
\text { Thrombosis }\end{array}$ & $0.8 \%$ & $\begin{array}{c}\text { Not } \\
\text { applicable }\end{array}$ & $\begin{array}{c}\text { Not } \\
\text { applicable }\end{array}$ \\
\hline $\begin{array}{c}\text { SPIRIT } \\
\text { Small } \\
\text { Vessel } \\
(\mathrm{SV})\end{array}$ & $\begin{array}{l}\text { Single-arm, } \\
\text { multicenter, } \\
\text { open label }\end{array}$ & 144 & $\begin{array}{c}\text { TLF at } 1 \\
\text { year }\end{array}$ & $8.1 \%$ & $\mathrm{PG}^{*} 20.4 \%$ & $\mathrm{P}<0.0001$ \\
\hline $\begin{array}{l}\text { SPIRIT } \\
\text { PRIME }\end{array}$ & $\begin{array}{l}\text { Single-arm, } \\
\text { multicenter, } \\
\text { open label }\end{array}$ & $\begin{array}{c}419 \mathrm{CSR}^{\diamond} \\
\text { arm } \\
110 \text { LLR } \\
\text { arm }\end{array}$ & $\begin{array}{l}\text { TLF at } 1 \\
\text { year }\end{array}$ & $\begin{array}{l}\text { CSR 6.5\% } \\
\text { LLR } 12.5 \%\end{array}$ & $\begin{array}{l}\text { PG 9.2\% } \\
\text { PG19.2\% }\end{array}$ & $\begin{array}{l}\mathrm{P}=0.034 \\
\mathrm{P}=0.048\end{array}$ \\
\hline
\end{tabular}

Of note, the XIENCE V stent is also distributed as the PROMUS EES by Boston Scientific.

* PG = performance goal; ${ }^{\circ} \mathrm{CSR}=$ Core Sample Registry; ${ }^{\wedge} \mathrm{LLR}=$ Long Lesion Registry

Table 5. Clinical Trials evaluating the XIENCE V and the XIENCE PRIME everolimuseluting stents

\section{Longterm trial results}

Key trials discussed above have already completed or are reaching the final year of followup. The question of improved clinical outcomes with DES over BMS has been established with long-term safety profiles available from all of the leading manufacturers. The question 
of which DES has sustained the most improved clinical outcomes remains debatable depending on the patient needs and ability to adhere to the indicated dual antiplatelet therapy recommended of aspirin and clopidogrel, as per the DES PCI recommendations (King et al., 2007). The long-term follow-up available from key DES trials is presented in Table 6.

\begin{tabular}{|c|c|c|c|c|c|c|c|}
\hline Trial & $\begin{array}{l}\text { Treatment } \\
\text { Arms }\end{array}$ & $\begin{array}{c}\text { Follow-up } \\
\text { Year }\end{array}$ & $\begin{array}{c}\text { Cardiac } \\
\text { death } \\
\%\end{array}$ & MI \% & TLR \% & TVR \% & $\begin{array}{c}\text { Stent } \\
\text { Thrombosis } \\
\text { (ARC } \\
\text { def/prob \%) }\end{array}$ \\
\hline \multirow{2}{*}{$\begin{array}{c}\text { RAVEL } \\
\text { (Morice et al., } \\
\text { 2007) }\end{array}$} & CYPHER SES & \multirow[b]{2}{*}{5} & 12.1 & 8.9 & 10.3 & 2.7 & 3.3 \\
\hline & BMS & & $\begin{array}{c}7.1 \\
\text { (all } \\
\text { death) }\end{array}$ & 6.9 & $\begin{array}{c}26.0 \\
P<0.001\end{array}$ & 2.6 & $\begin{array}{c}6.8 \\
\text { (all ARC) }\end{array}$ \\
\hline \multirow[t]{2}{*}{ SIRIUS } & CYPHER SES & & 4.1 & 6.2 & 9.4 & 16.5 & 1.2 \\
\hline & BMS & 5 & 3.6 & 6.5 & $\begin{array}{c}24.2 \\
P<0.001\end{array}$ & $\begin{array}{c}30.5 \\
P<0.001\end{array}$ & 1.8 \\
\hline \multirow{2}{*}{$\begin{array}{c}\text { TAXUS IV } \\
\text { (Ellis et al., } \\
\text { 2009a) }\end{array}$} & $\begin{array}{c}\text { TAXUS } \\
\text { Express PES }\end{array}$ & \multirow[b]{2}{*}{5} & 4.4 & 7.2 & 9.1 & 16.9 & 2.2 \\
\hline & BMS & & 4.5 & 7.4 & $\begin{array}{c}20.5 \\
P<0.0001\end{array}$ & $\begin{array}{c}27.4 \\
P<0.0001\end{array}$ & 2.1 \\
\hline \multirow{2}{*}{$\begin{array}{c}\text { TAXUS V } \\
\text { (Ellis et al., } \\
2009 b)\end{array}$} & $\begin{array}{c}\text { TAXUS } \\
\text { Express PES }\end{array}$ & \multirow{2}{*}{5} & & 8.4 & & \multirow{2}{*}{$\begin{array}{c}\text { Not } \\
\text { available }\end{array}$} & 1.9 \\
\hline & BMS & & $\begin{array}{c}1.6 \\
P=0.04\end{array}$ & 5.4 & $\begin{array}{c}22.3 \\
\mathrm{P}=0.005\end{array}$ & & 0.7 \\
\hline \multirow{2}{*}{$\begin{array}{c}\text { ENDEAVOR } \\
\text { III } \\
\text { (Kandzari et } \\
\text { al., 2011) }\end{array}$} & ENDEAVOR & \multirow[b]{2}{*}{5} & $0.3 \%$ & $1.0 \%$ & $8.1 \%$ & $16.9 \%$ & $0.7 \%$ \\
\hline & $\begin{array}{c}\text { ZES } \\
\text { CYPHER SES }\end{array}$ & & $2.8 \%$ & $\begin{array}{c}4.6 \% \\
P=0.03\end{array}$ & $6.5 \%$ & $13.0 \%$ & $0.9 \%$ \\
\hline \multirow{2}{*}{$\begin{array}{c}\text { ENDEAVOR } \\
\text { IV } \\
\text { (Leon et al., } \\
\text { 2010) }\end{array}$} & $\begin{array}{c}\text { ENDEAVOR } \\
\text { ZES }\end{array}$ & \multirow[b]{2}{*}{3} & 1.7 & 2.1 & 6.5 & 9.9 & 1.1 \\
\hline & $\begin{array}{c}\text { TAXUS } \\
\text { Express PES }\end{array}$ & & 2.4 & $\begin{array}{c}4.9 \\
\mathrm{P}=0.005\end{array}$ & 6.1 & 10.9 & 1.7 \\
\hline \multirow[b]{2}{*}{$\begin{array}{c}\text { SPIRIT III } \\
\text { (Stone, 2010b) }\end{array}$} & XIENCE V & \multirow[b]{2}{*}{4} & 2.6 & 4.4 & 7.6 & 13.4 & 1.4 \\
\hline & $\begin{array}{l}\text { TAXUS } \\
\text { Express } \\
\end{array}$ & & 2.6 & 6.6 & 10.3 & 16.1 & 1.6 \\
\hline \multirow{3}{*}{$\begin{array}{c}\text { SPIRIT IV } \\
\text { (Stone, 2010a) }\end{array}$} & XIENCE V & & $0.9 \%$ & $2.5 \%$ & & & \\
\hline & TAXUS & 2 & $1.3 \%$ & $3.9 \%$ & $4.5 \%$ & $3.9 \%$ & $0.42 \%$ \\
\hline & Express & & & $(\mathrm{P}=0.02)$ & $(\mathrm{P}=0.004)$ & & $\begin{array}{c}1.23 \% \\
(\mathrm{P}=0.008)\end{array}$ \\
\hline
\end{tabular}

(Available significant $P$ values $(\leq 0.05)$ are included above).

Table 6. Long-term Clinical Outcomes Currently Available 


\section{Current challenges}

A challenge that remains when comparing DES head to head across trials is the inconsistency between definitions. In order to address this challenge, the Academic Research Consortium (ARC) developed standardized definitions for clinical trial endpoints (Cutlip et al., 2007). The ARC definitions have now become the gold standard for clinical trial endpoints and definitions of clinical events, such as cardiac deaths, MI, and ST. In addition, clinical events may be retrospectively adjudicated by Clinical Events Committees (CEC) using the ARC definitions for post ad-hoc analysis of events not initially evaluated using the ARC definitions. The ARC definitions particularly met the need of unifying the ST definition that differed across stent manufacturers and clinical trials. One of the main concerns with using DES initially was the additional risk of ST possibly due to delayed healing, inflammation or incompatibility between polymer and the vessel (Lagerqvist et al., 2007; Moreno et al., 2005). First generation DES have observed higher rates of very late ST compared to BMS (Camenzind et al., 2007; Daemen et al., 2007; Farb and Boam, 2007; Pfisterer et al., 2006). Several DES specific characteristics may contribute to the development of ST, such as choice of drug, polymer, and strut thickness. Other patient specific characteristics may contribute, such as patient co-morbidities (diabetes, renal failure and acute MI) and lesion characteristics. Compliance to DAPT and platelet responsiveness also plays a role in ST rates observed in DES (Bezenek et al., 2011). Procedural factors related to smaller luminal dimensions, such as stent under-expansion or malapposition are risk factors for ST, in addition to stent length, multi-stenting, persistent slow flow, positive remodeling, dissections, geographic miss, residual stenosis, and late stent malapposition which have all been related to ST (Bezenek et al., 2011). Furthermore, well established criteria for the duration and dose with existing antiplatelet medication, as well as the role of newly emerging antiplatelet medications does not exist currently. Although the ARC definitions did provide a common reference for ST definitions concerning timing and severity, the appropriate standardized dose of DAPT remains in question with DES use. Despite these challenges however, few DES have emerged as demonstrating a consistent numerically low rate of ST across clinical trials. The XIENCE V and XIENCE PRIME DES remain two of the DES with the lowest ST event profile across RCT, single-arm, and all-comer trials, despite reduced DAPT compliance observed at 2 years in the COMPARE all-comers trial; the combination of stent design, thin struts, bio-compatible polymer coating technologies, and drug may contribute to numerically low ST rates consistently observed (Bezenek et al., 2011).

\section{Additional stent technology}

In order to address the concern for potential increased risk of late/very late ST with DES, several manufacturers developed biodegradable polymers and bioabsorbable scaffolds that degrade over time. Durable polymers may be associated with increased complications and clinical events and new developments in DES are integrating dissolvable polymers and scaffolds to eliminate this potential problem. Abbott Vascular currently has the ABSORB ${ }^{\mathrm{TM}}$ clinical trial program that is evaluating the everolimus-eluting bioresorbable vascular scaffold (BVS) in global clinical trials. The ABSORB BVS clinical trial program is evaluating the safety and efficacy of fully bioabsorbable scaffold that is comprised of a poly-L-lactic acid backbone and has a poly-D, L-lactic acid coating that modulates the release of everolimus. The ABSORB international clinical trials that have enrolled patients thus far 
include ABSORB Cohorts A and Cohort B and ABSORB EXTEND. The ABSORB Cohort A trial enrolled 30 patients and was designed to evaluate the safety and performance of ABSORB BVS in single de novo lesions. The 4-year clinical event rates remain numerically low with no events of scaffold thrombosis occurring (Chevalier, 2011). The ABSORB Cohort $B$ trial enrolled 101 patients and allowed up to two de novo lesions to be treated. Current 12month results for Cohort B were presented at the American College of Cardiology (ACC) and reported that no scaffold thrombosis have occurred either by ARC or per protocol definitions as well (Serruys, 2011). The ABSORB EXTEND trial plans to enroll up to 1000 patients at up to 100 international sites and will continue to assess the safety and performance of ABSORB BVS in up to two de novo lesions, allowing for the evaluation of longer lesions and overlapping scaffolds.

As mentioned earlier, the NEVO stent was a new technology in development by Cordis Corporation, Johnson and Johnson, and used polylactic-co-glycolic acid (PGLA) loaded in reservoirs drilled through the struts of a cobalt chromium stent and has subsequently been removed from further development (Belardi, 2011; Otake et al., 2011b). The JACTAX ${ }^{\mathrm{TM}}$ biodegradable stent system is developed by Boston Scientific and uses D-lactic polylactic acid (DLPLA) mounted on the TAXUS Liberté stent whose outside coating elutes paclitaxel (Grube et al., 2010; Shand, 2010) . The Biolimus-A9 TM eluting BioMatrix ${ }^{\mathrm{TM}}$ stent system (Biosensors Interventional Technologies Pte Ltd, Singapore) incorporates a biodegradable polylactic acid (PLA) coated on the outside of the S-Stent stainless steel stent that scaffolds the artery (Abizaid et al., 2011; Shand, 2010). The Leaders trial was designed to compare the BioMatrix stent to the CYPHR stent and enrolled 1707 patients (randomized 1:1) with a composite clinical primary endpoint of cardiac death, MI, and clinically-indicated target vessel revascularization (Windecker et al., 2008). The primary endpoint was met and BioMatrix demonstrated non-inferiority compared to CYPHER $(9.2 \%$ versus $10.5 \%$; $\mathrm{P}=0.003)$ and has sustained numerically low rats of very-late ARC-defined definite stent thrombosis through 3 years, respectively (0.2\% versus 0.9\%), (Windecker, 2011; Windecker et al., 2008).

The CardioMind Sparrow is developed by CardioMind, Inc. and is a self-expandable nitinol stent with a PLA/PLGA copolymer biodegradable outside coating (Abizaid et al., 2011). The ELIXER-DESTM is under development by the Elixer Medical Group and has a cobaltchromium stent as the scaffold and uses polyester or polylactide based biodegradable polymer coating over the outside of the stent. Other technologies are moving toward polymer-free DES as well, such as the BioFreedom ${ }^{\mathrm{TM}}$ (Biosensors Inc.), the VESTAsync ${ }^{\mathrm{TM}}$ (MIV Therapeutics), and the Optima ${ }^{\mathrm{TM}}$ (CID S.r.I) with further specialized designs using biolimus A9, sirolimus, and tacrolimus, respectively (Abizaid et al., 2011). Lastly, endothelium progenitor cell (EPC) capture stents were developed (Genous ${ }^{\mathrm{TM}}$ manufactured by OrbusNeich, Florida, USA) coated with CD34 antibodies that were to bind to circulating EPCs. The EPC capture stents have yet to show clinical trials demonstrating safety and efficacy superior to DES and have not become mainstream treatment options to date (Garg et al., 2010).

\section{Conclusion}

In conclusion, DES has emerged as a treatment of choice for patients that are suitable candidates with no restrictions to physician recommended DAPT medication. The first and 
next generation DES evaluated in the CYPHER, TAXUS, ENDEAVOR, and XIENCE V clinical programs significantly reduced restenosis compared to BMS and have demonstrated comparable safety outcomes. In order to address potential polymer induced inflammation or delayed healing related safety events in current FDA approved DES, new technologies using biodegradable polymers, polymer-free DES, and bioresorbable stent scaffolds have emerged to further enhance PCI options. Long-term clinical results have clearly supported the safety and efficacy of DES and more specialized DES designs and trials for specific patient and lesion unmet needs continue to be pursued.

\section{References}

Abizaid A., Costa J.R., Jr., Feres F. (2011) First nine-month complete invasive assessment (angiography, IVUS, and OCT) of the novel NEVO sirolimus-eluting stent with biodegradable polymer. Catheterization and Cardiovascular Interventions 77:49-51. DOI: $10.1002 /$ ccd.22558.

Acharya G., Park K. (2006) Mechanisms of controlled drug release from drug-eluting stents. Adv Drug Deliv Rev 58:387-401.

Ako J., Bonneau H.N., Honda Y., Fitzgerald P.J. (2007) Design criteria for the ideal drugeluting stent. American Journal of Cardiology 100:3M-9M.

Belardi J.A. (2011) Nevo stent: a successful stent makeover. Catheter Cardiovasc Interv 77:52-3. DOI: $10.1002 /$ ccd.22921.

Bezenek S., Hermiller J., Lansky A., Yaqub M., Hattori K., Cao S., Sood P., Sudhir K. (2011) Low stent thrombosis risk with the XIENCE V(R) everolimus-eluting coronary stent: Evidence from randomized and single-arm clinical trials. Journal of Interventional Cardiology:DOI: 10.1111/j.1540-8183.2011.00628.x. DOI: 10.1111/j.1540-8183.2011.00628.x.

Camenzind E., Steg P.G., Wijns W. (2007) Stent thrombosis late after implantation of firstgeneration drug-eluting stents: a cause for concern. Circulation 115:1440-1455.

Chevalier B. (2011) ABSORB Cohort B Trial - Evaluation of the ABSORB Bioresorbable Everolimus-Eluting Vascular Scaffold in the Treatment of Patients with de novo Native Coroanry Artery Lesions, Amercian College of Cardiology, netherlands.

Colombo A., Drzewiecki J., Banning A., Grube E., Hauptmann K., Silber S., Dudek D., Fort S., Schiele F., Zmudka K., Guagliumi G., Russell M.E. (2003) Randomized study to assess the effectiveness of slow- and moderate-release polymer-based paclitaxeleluting stents for coronary artery lesions. Circulation 108:788-794.

Cutlip D.E., Windecker S., Mehran R., Boam A., Cohen D.J., van Es G.A., Steg P.G., Morel M.A., Mauri L., Vranckx P., McFadden E., Lansky A., Hamon M., Krucoff M.W., Serruys P.W. (2007) Clinical end points in coronary stent trials: a case for standardized definitions. Circulation 115:2344-2351.

Daemen J., Wenaweser P., Tsuchida K., Abrecht L., Vaina S., Morger C., Kukreja N., Juni P., Sianos G., Hellige G., van Domburg R.T., Hess O.M., Boersma E., Meier B., Windecker S., Serruys P.W. (2007) Early and late coronary stent thrombosis of sirolimus-eluting and paclitaxel-eluting stents in routine clinical practice: data from a large two-institutional cohort study. Lancet 369:667-678.

Dawkins K.D., Grube E., Guagliumi G., Banning A.P., Zmudka K., Colombo A., Thuesen L., Hauptman K., Marco J., Wijns W., Popma J.J., Koglin J., Russell M.E. (2005) Clinical efficacy of polymer-based paclitaxel-eluting stents in the treatment of complex, 
long coronary artery lesions from a multicenter, randomized trial: support for the use of drug-eluting stents in contemporary clinical practice. Circulation 112:33063313. 10.1161/CIRCULATIONAHA.105.552190.

Dobies D. (2007) ARRIVE I at 2 years, EuroPCR, Barcelona, Spain.

Doostzadeh J., Bezenek S., Cheong W.-F., Sood P., Schwartz L.B., Sudhir K. (2009) Clinical trials in interventional cardiology: focus on the XIENCE drug-eluting stent, in: S. C. Gad (Ed.), Clinical Trials Handbook, Wiley, Hoboken. pp. 397-435.

Doostzadeh J., Clark L.N., Bezenek S., Pierson W., Sood P.R., Sudhir K. (2010) Recent progress in percutaneous coronary intervention: evolution of the drug-eluting stents, focus on the XIENCE V drug-eluting stent. Coronary Artery Disease 21:4656. DOI: 10.1097/MCA.0b013e328333f550.

Fajadet J., Wijns W., Laarman G.J., Kuck K.H., Ormiston J., Munzel T., Popma J.J., Fitzgerald P.J., Bonan R., Kuntz R.E. (2006) Randomized, double-blind, multicenter study of the Endeavor zotarolimus-eluting phosphorylcholine-encapsulated stent for treatment of native coronary artery lesions: clinical and angiographic results of the ENDEAVOR II trial. Circulation 114:798-806.

Farb A., Boam A.B. (2007) Stent thrombosis redux--the FDA perspective. New England Journal of Medicine 356:984-987.

FDA. (2006) Circulatory System Devices Advisory Panel.

Fischman D.L., Leon M.B., Baim D.S., Schatz R.A., Savage M.P., Penn I., Detre K., Veltri L., Ricci D., Nobuyoshi M., et al. (1994) A randomized comparison of coronary-stent placement and balloon angioplasty in the treatment of coronary artery disease. New England Journal of Medicine 331:496-501. DOI: 10.1056/NEJM199408253310802.

Garcia-Touchard A., Burke S.E., Toner J.L., Cromack K., Schwartz R.S. (2006) Zotarolimuseluting stents reduce experimental coronary artery neointimal hyperplasia after 4 weeks. European Heart Journal 27:988-993.

Grube E., Silber S., Hauptmann K.E., Mueller R., Buellesfeld L., Gerckens U., Russell M.E. (2003) TAXUS I: six- and twelve-month results from a randomized, double-blind trial on a slow-release paclitaxel-eluting stent for de novo coronary lesions. Circulation 107:38-42.

Grube E., Schofer J., Hauptmann K.E., Nickenig G., Curzen N., Allocco D.J., Dawkins K.D. (2010) A novel paclitaxel-eluting stent with an ultrathin abluminal biodegradable polymer 9-month outcomes with the JACTAX HD stent. JACC Cardiovasc Interv 3:431-8.

Halkin A., Stone G.W. (2004) Polymer-based paclitaxel-eluting stents in percutaneous coronary intervention: a review of the TAXUS trials. Journal of Intervational Cardiology 17:271-182.

Hellige G., Windecker S. (2009) Head-to-head and extrapolated comparisons of different drug-eluting stents: differences in late loss, restenosis, and clinical outcomes. Journal of Interventional Cardiology 22:S48-S63.

Hermiller J. (2010) Early and late stent thrombosis rates in 5,054 real-world patients from XIENCE V USA with and without dual antiplatelet therapy interruptions, EuroPCR, Paris.

Holmes D.R. (2003) 12-month clinical follow-up from SIRIUS, ACC Chicago, USA.

Htay T., Liu M.W. (2005) Drug-eluting stent: a review and update. Vascular Health Risk Management 1:263-276. 
Joner M., Finn A.V., Farb A., Mont E.K., Kolodgie F.D., Ladich E., Kutys R., Skorija K., Gold H.K., Virmani R. (2006) Pathology of drug-eluting stents in humans: delayed healing and late thrombotic risk. J Am Coll Cardiol 48:193-202.

Joner M., Nakazawa G., Finn A.V., Quee S.C., Coleman L., Acampado E., Wilson P.S., Skorija K., Cheng Q., Xu X., Gold H.K., Kolodgie F.D., Virmani R. (2008) Endothelial cell recovery between comparator polymer-based drug-eluting stents. Journal of the American College of Cardiology 52:333-42.

Kandzari D.E., Leon M.B., Popma J.J., Fitzgerald P.J., O'Shaughnessy C., Ball M.W., Turco M., Applegate R.J., Gurbel P.A., Midei M.G., Badre S.S., Mauri L., Thompson K.P., LeNarz L.A., Kuntz R.E. (2006) Comparison of zotarolimus-eluting and sirolimus-eluting stents in patients with native coronary artery disease: a randomized controlled trial. Journal of the American College of Cardiology 48:2440-2447.

Kastrati A., Mehilli J., Dirschinger J., Dotzer F., Schuhlen H., Neumann F.J., Fleckenstein M., Pfafferott C., Seyfarth M., Schomig A. (2001) Intracoronary stenting and angiographic results: strut thickness effect on restenosis outcome (ISAR-STEREO) trial. Circulation 103:2816-2821.

King S.B. (2007) Applying drug-eluting stents in clinical practice. American Journal of Cardiology 100:25K-31K.

King S.B., 3rd, Aversano T., Ballard W.L., Beekman R.H., 3rd, Cowley M.J., Ellis S.G., Faxon D.P., Hannan E.L., Hirshfeld J.W., Jr., Jacobs A.K., Kellett M.A., Jr., Kimmel S.E., Landzberg J.S., McKeever L.S., Moscucci M., Pomerantz R.M., Smith K.M., Vetrovec G.W., Creager M.A., Holmes D.R., Jr., Newby L.K., Weitz H.H., Merli G., Pina I., Rodgers G.P., Tracy C.M. (2007) ACCF/AHA/SCAI 2007 update of the Clinical Competence Statement on Cardiac Interventional Procedures: a report of the American College of Cardiology Foundation/American Heart Association/American College of Physicians Task Force on Clinical Competence and Training (Writing Committee to Update the 1998 Clinical Competence Statement on Recommendations for the Assessment and Maintenance of Proficiency in Coronary Interventional Procedures). Circulation 116:98-124.

Lagerqvist B., James S.K., Stenestrand U., Lindback J., Nilsson T., Wallentin L. (2007) Longterm outcomes with drug-eluting stents versus bare-metal stents in Sweden. New England Journal of Medicine 356:1009-1019.

Lasala J.M., Stone G.W., Dawkins K.D., Serruys P.W., Colombo A., Grube E., Koglin J., Ellis S. (2006) An overview of the TAXUS Express, paclitaxel-eluting stent clinical trial program. Journal of Interventional Cardiology 19:422-31.

Leon M.B. (2011) Clinical evaluation of the RESOLUTE zotarolimus-eluting coronary stent system in the treatment of de novo lesions in native coronary arteries (the RESOLUTE US clinical trial), ACC, New Orleans, USA.

Leon M.B., Nikolsky E., Cutlip D.E., Mauri L., Liberman H., Wilson H., Patterson J., Moses J., Kandzari D.E. (2010) Improved late clinical safety with zotarolimus-eluting stents compared with paclitaxel-eluting stents in patients with de novo coronary lesions: 3-year follow-up from the ENDEAVOR IV (Randomized Comparison of Zotarolimus- and Paclitaxel-Eluting Stents in Patients With Coronary Artery Disease) trial. JACC Cardiovasc Interv 3:1043-50.

Leon M.B., Kandzari D.E., Eisenstein E.L., Anstrom K.J., Mauri L., Cutlip D.E., Nikolsky E., O'Shaughnessy C., Overlie P.A., Kirtane A.J., McLaurin B.T., Solomon S.L., Douglas 
J.S., Jr., Popma J.J. (2009) Late safety, efficacy, and cost-effectiveness of a zotarolimus-eluting stent compared with a paclitaxel-eluting stent in patients with de novo coronary lesions: 2-year follow-up from the ENDEAVOR IV trial (Randomized, Controlled Trial of the Medtronic Endeavor Drug [ABT-578] Eluting Coronary Stent System Versus the Taxus Paclitaxel-Eluting Coronary Stent System in De Novo Native Coronary Artery Lesions). Journal of the American College of Cardiology: Cardiovascular Interventions 2:1208-1218.

Maeng M., Holm N.R., Kaltoft A., Jensen L.O., Tilsted H.H., Thuesen L., Lassen J.F. (2010) Zotarolimus-eluting versus sirolimus-eluting coronary stent implantation. Interventional Cardiology 2:807-812.

Meredith I.T. (2011) Platinum small vessel 12-month outcomes, EuroPCR, Paris, France.

Meredith I.T., Ormiston J., Whitbourn R., Kay I.P., Muller D., Bonan R., Popma J.J., Cutlip D.E., Fitzgerald P., Prpic R., Kuntz R.E. (2005) First-in-human study of the Endeavor ABT578-eluting phosphorylcholine-encapsulated stent system in de novo native coronary artery lesions: Endeavor I Trial. EuroIntervention 1:157-164. DOI: EIJV1I2A26 [pii].

Meredith I.T., Worthley S., Whitbourn R., Walters D.L., McClean D., Horrigan M., Popma J.J., Cutlip D.E., DePaoli A., Negoita M., Fitzgerald P.J. (2009) Clinical and angiographic results with the next-generation resolute stent system: a prospective, multicenter, first-in-human trial. Journal of the American College of Cardiology: Cardiovascular Interventions 2:977-985.

Moreno R., Fernandez C., Hernandez R., Alfonso F., Angiolillo D.J., Sabate M., Escaned J., Banuelos C., Fernandez-Ortiz A., Macaya C. (2005) Drug-eluting stent thrombosis: results from a pooled analysis including 10 randomized studies. Journal of the American College of Cardiology 45:954-959.

Morice M.C., Serruys P.W., Barragan P., Bode C., Van Es G.A., Stoll H.P., Snead D., Mauri L., Cutlip D.E., Sousa E. (2007) Long-term clinical outcomes with sirolimus-eluting coronary stents: five-year results of the RAVEL trial. Journal of the American College of Cardiology 50:1299-1304.

Morice M.C., Serruys P.W., Sousa J.E., Fajadet J., Ban Hayashi E., Perin M., Colombo A., Schuler G., Barragan P., Guagliumi G., Molnar F., Falotico R. (2002) A randomized comparison of a sirolimus-eluting stent with a standard stent for coronary revascularization. New England Journal of Medicine 346:1773-1780.

Moses J.W., Leon M.B., Popma J.J., Fitzgerald P.J., Holmes D.R., O'Shaughnessy C., Caputo R.P., Kereiakes D.J., Williams D.O., Teirstein P.S., Jaeger J.L., Kuntz R.E. (2003) Sirolimus-eluting stents versus standard stents in patients with stenosis in a native coronary artery. New England Journal of Medicine 349:1315-1323.

Otake H., Honda Y., Courtney B.K., Shimohama T., Ako J., Waseda K., Macours N., Rogers C., Popma J.J., Abizaid A., Ormiston J.A., Spaulding C., Cohen S.A., Fitzgerald P.J. (2011a) Intravascular ultrasound results from the NEVO ResElution-I trial: a randomized, blinded comparison of sirolimus-eluting NEVO stents with paclitaxeleluting TAXUS Liberte stents in de novo native coronary artery lesions. Circulation: Cardiovascular Interventions 4:146-154.

Otake H., Honda Y., Courtney B.K., Shimohama T., Ako J., Waseda K., Macours N., Rogers C., Popma J.J., Abizaid A., Ormiston J.A., Spaulding C., Cohen S.A., Fitzgerald P.J. (2011b) Intravascular ultrasound results from the NEVO ResElution-I trial: a randomized, blinded comparison of sirolimus-eluting NEVO stents with paclitaxel- 
eluting TAXUS Liberte stents in de novo native coronary artery lesions. Circ Cardiovasc Interv 4:146-54.

Pfisterer M., Brunner-La Rocca H.P., Buser P.T., Rickenbacher P., Hunziker P., Mueller C., Jeger R., Bader F., Osswald S., Kaiser C. (2006) Late clinical events after clopidogrel discontinuation may limit the benefit of drug-eluting stents: an observational study of drug-eluting versus bare-metal stents. Journal of the American College of Cardiology 48:2584-2591.

Roger V.L., Go A.S., Lloyd-Jones D.M., Adams R.J., Berry J.D., Brown T.M., Carnethon M.R., Dai S., de Simone G., Ford E.S., Fox C.S., Fullerton H.J., Gillespie C., Greenlund K.J., Hailpern S.M., Heit J.A., Ho P.M., Howard V.J., Kissela B.M., Kittner S.J., Lackland D.T., Lichtman J.H., Lisabeth L.D., Makuc D.M., Marcus G.M., Marelli A., Matchar D.B., McDermott M.M., Meigs J.B., Moy C.S., Mozaffarian D., Mussolino M.E., Nichol G., Paynter N.P., Rosamond W.D., Sorlie P.D., Stafford R.S., Turan T.N., Turner M.B., Wong N.D., Wylie-Rosett J. (2011) Heart disease and stroke statistics--2011 update: a report from the American Heart Association. Circulation 123:e18-e209.

Rowinsky E.K., Donehower R.C. (1995) Paclitaxel (taxol). New England Journal of Medicine 332:1004-1014. DOI: 10.1056/NEJM199504133321507.

Schampaert E., Cohen E.A., Schluter M., Reeves F., Traboulsi M., Title L.M., Kuntz R.E., Popma J.J. (2004) The Canadian study of the sirolimus-eluting stent in the treatment of patients with long de novo lesions in small native coronary arteries (C-SIRIUS). Journal of the American College of Cardiology 43:1110-1115.

Schofer J., Schluter M., Gershlick A.H., Wijns W., Garcia E., Schampaert E., Breithardt G. (2003) Sirolimus-eluting stents for treatment of patients with long atherosclerotic lesions in small coronary arteries: double-blind, randomised controlled trial (ESIRIUS). Lancet 362:1093-1099.

Serruys P.W. (2011) ABSORB: Evaluation of the Bioresorbable Everolimus-Eluting Vascular Scaffold (BVS) in the Treatment of Patients with De Novo Native Coronary Artery Lesions: 1 Year Angiographic, IVUS, IVUS-VH and OCT results of Cohort B., American College of Cardiology, Netherlands.

Serruys P.W., Regar E., Carter A.J. (2002a) Rapamycin eluting stent: the onset of a new era in interventional cardiology. Heart 87:305-307.

Serruys P.W., de Jaegere P., Kiemeneij F., Macaya C., Rutsch W., Heyndrickx G., Emanuelsson H., Marco J., Legrand V., Materne P., et al. (1994) A comparison of balloon-expandable-stent implantation with balloon angioplasty in patients with coronary artery disease. New England Journal of Medicine 331:489-495. DOI: 10.1056/NEJM199408253310801.

Serruys P.W., Degertekin M., Tanabe K., Abizaid A., Sousa J.E., Colombo A., Guagliumi G., Wijns W., Lindeboom W.K., Ligthart J., de Feyter P.J., Morice M.C. (2002b) Intravascular ultrasound findings in the multicenter, randomized, double-blind RAVEL (RAndomized study with the sirolimus-eluting VElocity balloonexpandable stent in the treatment of patients with de novo native coronary artery Lesions) trial. Circulation 106:798-803.

Shand J. (2010) Drug-eluting stents: the next generation. Interv. Cardiol. 2:341-350.

Sousa J.E., Costa M.A., Abizaid A., Abizaid A.S., Feres F., Pinto I.M., Seixas A.C., Staico R., Mattos L.A., Sousa A.G., Falotico R., Jaeger J., Popma J.J., Serruys P.W. (2001) Lack of neointimal proliferation after implantation of sirolimus-coated stents in human 
coronary arteries: a quantitative coronary angiography and three-dimensional intravascular ultrasound study. Circulation 103:192-195.

Spaulding C. (2011) The NEVO RES-1 study: a randomized, multi-center comparison of the NEVO reservoir-based sirolimus-eluting stent with the TAXUS Liberte paclitaxeleluting stent: 2-year outcomes, EuroPCR, Paris, France.

Stone G.W. (2010) Comparison of everolimus-eluting and paclitaxel-eluting stents: First report of the four-year clinical outcomes from the SPIRIT III trial, TCT, Washington D.C., USA.

Stone G.W., Ellis S.G., O'Shaughnessy C.D., Martin S.L., Satler L., McGarry T., Turco M.A., Kereiakes D.J., Kelley L., Popma J.J., Russell M.E. (2006) Paclitaxel-eluting stents vs vascular brachytherapy for in-stent restenosis within bare-metal stents: the TAXUS V ISR randomized trial. Journal of the American Medical Association 295:1253-1263.

Stone G.W., Ellis S.G., Cannon L., Mann J.T., Greenberg J.D., Spriggs D., O'Shaughnessy C.D., DeMaio S., Hall P., Popma J.J., Koglin J., Russell M.E. (2005) Comparison of a polymer-based paclitaxel-eluting stent with a bare metal stent in patients with complex coronary artery disease: a randomized controlled trial. Journal of the American Medical Association 294:1215-1223.

Tanabe K., Serruys P.W., Grube E., Smits P.C., Selbach G., van der Giessen W.J., Staberock M., de Feyter P., Muller R., Regar E., Degertekin M., Ligthart J.M., Disco C., Backx B., Russell M.E. (2003) TAXUS III Trial: in-stent restenosis treated with stent-based delivery of paclitaxel incorporated in a slow-release polymer formulation. Circulation 107:559-564.

Turco M. (2008) TAXUS ATLAS 3-Year Clinical Results, TCT, Washington, D.C, USA.

Weisz G., Leon M.B., Holmes D.R., Jr., Kereiakes D.J., Clark M.R., Cohen B.M., Ellis S.G., Coleman P., Hill C., Shi C., Cutlip D.E., Kuntz R.E., Moses J.W. (2006) Two-year outcomes after sirolimus-eluting stent implantation: results from the SirolimusEluting Stent in de Novo Native Coronary Lesions (SIRIUS) trial. Journal of the American College of Cardiology 47:1350-1355.

Windecker S. (2011) BioMatrix Flx - New Generation DES, Euro-PCR, Europe.

Windecker S., Serruys P.W., Wandel S., Buszman P., Trznadel S., Linke A., Lenk K., Ischinger T., Klauss V., Eberli F., Corti R., Wijns W., Morice M.C., di Mario C., Davies S., van Geuns R.J., Eerdmans P., van Es G.A., Meier B., Juni P. (2008) Biolimus-eluting stent with biodegradable polymer versus sirolimus-eluting stent with durable polymer for coronary revascularisation (LEADERS): a randomised non-inferiority trial. Lancet 372:1163-73.

Yeung A.C., Leon M.B., Jain A., Tolleson T.R., Spriggs D.J., Mc Laurin B.T., Popma J.J., Fitzgerald P.J., Cutlip D.E., Massaro J.M., Mauri L. (2011) Clinical evaluation of the RESOLUTE zotarolimus-eluting coronary stent system in the treatment of de novo lesions in native coronary arteries: the RESOLUTE US clinical trial. Journal of the American College of Cardiology 57:1778-1783. 


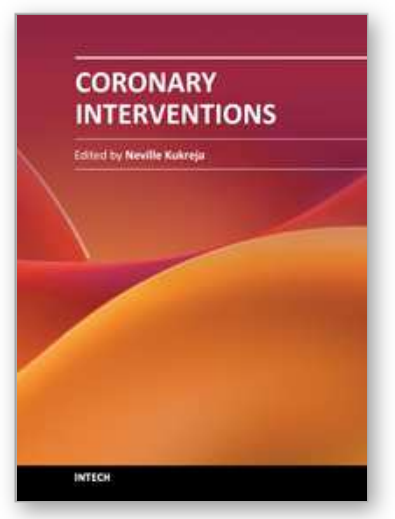

\author{
Coronary Interventions \\ Edited by Dr. Neville Kukreja
}

ISBN 978-953-51-0498-8

Hard cover, 244 pages

Publisher InTech

Published online 18, April, 2012

Published in print edition April, 2012

\title{
How to reference
}

In order to correctly reference this scholarly work, feel free to copy and paste the following:

Susan Bezenek, Poornima Sood, Wes Pierson, Chuck Simonton and Krishna Sudhir (2012). DES Overview: A Historical and Current Review of Pivotal Clinical Trial Programs, Coronary Interventions, Dr. Neville Kukreja (Ed.), ISBN: 978-953-51-0498-8, InTech, Available from: http://www.intechopen.com/books/coronaryinterventions/des-overview-a-historical-and-current-review-of-pivotal-clinical-trial-programs

\section{INTECH}

open science | open minds

\section{InTech Europe}

University Campus STeP Ri

Slavka Krautzeka 83/A

51000 Rijeka, Croatia

Phone: +385 (51) 770447

Fax: +385 (51) 686166

www.intechopen.com

\section{InTech China}

Unit 405, Office Block, Hotel Equatorial Shanghai

No.65, Yan An Road (West), Shanghai, 200040, China 中国上海市延安西路65号上海国际贵都大饭店办公楼405单元

Phone: +86-21-62489820

Fax: +86-21-62489821 
(C) 2012 The Author(s). Licensee IntechOpen. This is an open access article distributed under the terms of the Creative Commons Attribution 3.0 License, which permits unrestricted use, distribution, and reproduction in any medium, provided the original work is properly cited. 